\title{
EL LIBRE ACCESO A LAS ACTIVIDADES DE SERVICIOS Y SU APLICACIÓN EN EL ÁMBITO DE LAS ACTIVIDADES CLASIFICADAS. ESTUDIO DEL COMPORTAMIENTO NORMATIVO DE LAS COMUNIDADES AUTÓNOMAS ${ }^{1}$
}

\author{
ANNA PALLARÈS SERRANO \\ Profesora contratada doctora \\ Universitat Rovira i Virgili \\ Investigadora \\ Centre d'Estudis de Dret Ambiental de Tarragona \\ anna.pallares@urv.cat
}

Recibido: 1 de agosto de 2011 / Aceptado: 13 de octubre de 2011

RESUMEN: El objetivo de este trabajo es aclarar los mimbres sobre los que se ha de aplicar la normativa de servicios en el ámbito de la protección del medio ambiente y el entorno urbano, en general, y de las actividades clasificadas, en particular. A partir de este conocimiento detectamos las posibilidades ordenadoras de las diferentes comunidades autónomas en el ámbito de las actividades potencialmente lesivas para el medio ambiente y pasamos a realizar una radiografía y un análisis del comportamiento normativo de las diecisiete comunidades autónomas del Estado español para, finalmente, llegar a una serie de conclusiones generales que ayudan a vislumbrar los aciertos y desajustes del trabajo realizado y la tarea que aún quedaría pendiente de realizar.

\footnotetext{
${ }^{1}$ La profesora Anna Pallarès Serrano ha elaborado este artículo en el marco del proyecto de investigación DER2010-19343 sobre "Derecho ambiental y libertad de servicios en el mercado interior: nuevos retos, transformaciones y oportunidades", financiado por el Ministerio de Ciencia e Innovación. La elaboración de este trabajo se cierra el 15 de junio de 2012.
} 
RESUM: L'objectiu d'aquest treball es aclarir els aspectes bàsics sobre els que s'ha d'aplicar la normativa de serveis en l'àmbit de la protecció del medi ambient i de l'entorn urbà, en general, i de les activitats classificades, en particular. A partir d'aquest punt detectem les possibilitats reguladores de les diferents comunitats autònomes en l'àmbit de les activitats potencialment lesives pel medi ambient i passem a realitzar una radiografia i un anàlisi del comportament normatiu de les disset comunitats autònomes de l'estat espanyol per, finalment, arribar a una sèrie de conclusions generals que ajuden a veure els encerts i desajustos del treball realitzat i la tasca que encara quedaria pendent de portar a terme.

ABSTRACT: The aim of this study is to clarify the base on which the services regulation has to be applied in the field of environmental protection and urban environment and, particularly, in the domain of classified activities. Then, regulation possibilities of the different comunidades autónomas in the field of activities potentially harmful to the environment are analysed, along with the way how the different comunidades autónomas have proceeded. Finally, a series of general conclusions are presented, helping to discern the strengths and weakness of all the work done and the tasks remaining.

PALABRAS CLAVE: Directiva de Servicios - Interés general - actividades clasificadas.

PARAULES CLAU: Directiva de serveis — Interès general — activitats classificades.

KEY WORDS: Services Directive - Public interest - Classified activities.

Sumario: I. Introducción. II. Cuestiones que afectan a la materia protección del medio ambiente que hace que las actividades con incidencia ambiental se puedan regir por un régimen con especificidades diferenciadas en cada Comunidad Autónoma. 1. La protección del medio ambiente y del entorno urbano como ámbito incluido en el concepto de "razón imperiosa de interés general". 2. Los aspectos competenciales en materia de protección del medio ambiente. III. Estudio del comportamiento normativo de las comunidades autónomas en relación con la regulación de la libertad de establecimiento de las actividades potencialmente lesivas para el medio ambiente. 1. Canarias. 2. Aragón. 3. Cantabria. 4. Murcia. 5. Navarra. 6. Castilla y León. 7. Madrid. 8. Valencia. 9. La Rioja. 10. Cataluña. 11. País Vasco. 
12. Islas Baleares. 13. Andalucía. 14. Galicia.15. Asturias. 16. Castilla-La Mancha. 17. Extremadura. IV. Conclusiones. V. Bibliografía.

\section{INTRODUCCIÓN}

Desde el principio, en la Directiva 2006/123/CE del Parlamento Europeo y del Consejo, de 12 de diciembre de 2006, relativa a los servicios en el mercado interior (en adelante, la Directiva de Servicios $^{2}$ ), se deja muy claro que la liberalización de las actividades de servicios $^{3}$ se ha de hacer promoviendo, entre otras cuestiones, un alto nivel de protección y de mejora de la calidad del medio ambiente ${ }^{4}$. De manera que lo que se pretende con la regulación de la Directiva es conseguir el equilibrio entre la consecución del mercado interior de los servicios y la preservación de una serie de valores y conquistas sociales y ambientales de interés general ${ }^{5}$. Tomando en consideración este punto de partida, en este trabajo vamos a analizar el marco jurídico para materializar y articular este propósito $\mathrm{y}$, principalmente, las repercusiones $\mathrm{y}$ consecuencias que la consecución de este cometido ha tenido en el ámbito de las

\footnotetext{
${ }^{2}$ Encontramos un análisis pormenorizado de esta norma en diversos estudios. Citamos, como botón de muestra, los siguientes: LINDE PANIAGUA, E., "Notas sobre el objeto, ámbito y reglas de aplicación de la directiva relativa a los servicios en el mercado interior", en Revista de Derecho de la Unión Europea, núm. 14, 2008, pp. 35-46; ESTEVE GARCIA, F., "Los diferentes instrumentos de liberalización incluidos en la Directiva 2006/123 de servicios", en Revista catalana de dret públic, núm. 42, 2011, pp. 1-23; MONTERO PASCUAL, J., "La libre prestación de servicios en la directiva relativa a los servicios en el mercado interior", en Revista de Derecho de la Unión Europea, núm. 14, 2008, pp. 103-115; y LINDE PANIAGUA, E., "Libertad de establecimiento de los prestadores de servicios en la directiva relativa a los servicios en el mercado interior", en Revista de Derecho de la Unión Europea, núm. 14, 2008, pp. 83-101.

${ }^{3}$ En los considerandos 42 y 43 de la Directiva de Servicios se constata que el objetivo de dicha norma no es armonizar procedimientos, sino suprimir los regímenes de autorización, procedimientos y formalidades excesivamente onerosos que obstaculicen las libertades del tratado simplificando, en definitiva, las actuaciones administrativas.

${ }^{4}$ En el primer considerando de la Directiva se afirma que a la hora de eliminar las barreras que obstaculizan el desarrollo de las actividades de servicios entre los Estados miembros es esencial velar por el cumplimiento del artículo 2 del Tratado, que hace referencia a la tarea de promover "un desarrollo armonioso, equilibrado y sostenible de las actividades económicas en el conjunto de la Comunidad, un alto nivel de empleo y de protección social, la igualdad entre el hombre y la mujer, un crecimiento sostenible y no inflacionista, un alto grado de competitividad y de convergencia de los resultados económicos, un alto nivel de protección y de mejora de la calidad del medio ambiente, la elevación del nivel y de la calidad de vida, la cohesión económica y social y la solidaridad entre los Estados miembros". La cursiva es nuestra.

${ }^{5}$ Así, al final del considerando 4 se afirma lo siguiente: "Es importante, por consiguiente, realizar el mercado interior de los servicios con el debido equilibrio entre la apertura de los mercados y la preservación de los servicios públicos, los derechos sociales y los derechos de los consumidores"; y al final del considerando 7 se dice esto: "La presente Directiva también tiene en cuenta otros objetivos de interés general, incluida la protección del medio ambiente, la seguridad pública y la salud pública y la necesidad de ajustarse al Derecho del trabajo". Todos estos considerandos son un reflejo de que ni la libertad de establecimiento ni la libre prestación de servicios son absolutas y que ambas tienen como uno de sus límites la protección del medio ambiente. Vid. artículos 49 y 56 TFUE respectivamente.
} 
actividades potencialmente lesivas para el medio ambiente; en definitiva, en el ámbito de las actividades que tradicionalmente se han denominado clasificadas. Es decir, vamos a estudiar cómo se ordena la libertad de establecimiento y de prestación de servicios en el mercado interior teniendo en cuenta la necesidad de conseguir un alto nivel de protección y de mejora de la calidad del medio ambiente y, en concreto, cómo está afectando esta regulación a la ordenación de las actividades que pueden afectar al medio ambiente. Este ámbito de estudio es importante, sobre todo si tenemos en cuenta que nuestro legislador, al transponer la Directiva de Servicios, ha ido más allá de sus exigencias y ha incluido, dentro de las actividades que han de seguir este régimen liberalizador, a las actividades de fabricación de bienes, a las actividades industriales, que pueden tener una incidencia ambiental considerable.

Esta necesidad de conciliar ambos objetivos ha significado, por una parte, el establecimiento de una serie de reglas que pretenden eliminar las trabas y las barreras en el mercado interior de servicios y que ordenan, con carácter general, la libertad de establecimiento y la libre prestación de servicios, y, por otra, la disposición de la posibilidad de excepcionar estas normas siempre que concurran una serie de razones imperiosas de interés general, entre las que se encuentran, entre otras, la salud pública y la protección del medio ambiente y del entorno urbano ${ }^{6}$, y que estas excepciones no sean discriminatorias y que respeten el principio de proporcionalidad ${ }^{7}$.

Pasamos a mencionar y describir brevemente los postulados generales que han de ordenar la libertad de establecimiento y de prestación de servicios dentro de la Unión Europea, en general, y en el territorio del Estado español, en particular ${ }^{8}$ :

\footnotetext{
${ }^{6}$ El concepto de "razones imperiosas de interés general", al que se refiere en su articulado la Directiva de Servicios, ha sido desarrollado por el Tribunal de Justicia en su jurisprudencia relativa a los artículos 43 y 49 del Tratado. La noción incluye los siguientes ámbitos: orden público, seguridad pública y salud pública —en el sentido de los artículos 46 y 55 del Tratado-, mantenimiento del orden en la sociedad, objetivos de política social, protección de los destinatarios de los servicios, protección del consumidor, protección de los trabajadores —incluida su protección social_, bienestar animal, preservación del equilibrio financiero de los regímenes de seguridad social, prevención de fraudes, prevención de la competencia desleal, protección del medio ambiente y del entorno urbano —incluida la planificación urbana y rural-, protección de los acreedores, garantía de una buena Administración de justicia, seguridad vial, protección de la propiedad intelectual e industrial, objetivos de política cultural —incluida la salvaguardia de la libertad de expresión de los diversos componentes (en especial, los valores sociales, culturales, religiosos y filosóficos de la sociedad)—, la necesidad de garantizar un alto nivel de educación, mantenimiento de la diversidad de prensa, fomento de la lengua nacional, conservación del patrimonio nacional histórico y artístico y política veterinaria. Vid. considerando 40 y artículo 4 de la Directiva de Servicios.

${ }^{7}$ En este contexto, una excepción es proporcional siempre que sea adecuada para proteger el medio ambiente y siempre que no vaya más allá de lo necesario para alcanzar tal protección.
} 
- Se determina que no se puede exigir, al que quiera ejercer una actividad de servicios, el régimen de autorización, a no ser que concurran las siguientes condiciones: que el régimen de autorización no sea discriminatorio para el prestador en función de la nacionalidad o de que el establecimiento o el domicilio social se encuentre o no en el territorio de la autoridad competente, que el régimen de autorización esté justificado por una razón imperiosa de interés general y que el objetivo que se persiga con la autorización no se pueda conseguir mediante una medida menos restrictiva porque el control a posteriori tendría lugar demasiado tarde para ser realmente eficaz ${ }^{9}$. Esto significa que, con carácter general, el ejercicio de una actividad de servicios se vehiculará a través de mecanismos menos onerosos como la comunicación previa ${ }^{10} \mathrm{o}$ la declaración responsable ${ }^{11}$.

${ }^{8}$ Sobre el impacto de la Directiva de Servicios en nuestro derecho administrativo, consúltese, entre otros:
AGUADO CUDOLÀ, V. y NOGUERA DE LA MUELA, B. (dirs.), El impacto de la Directiva de
Servicios en las Administraciones Públicas: aspectos generales y sectoriales, Atelier, Barcelona, 2012;
RAZQUIN LIZARRAGA, J., "El impacto de la Directiva de servicios en el procedimiento
administrativo: autorización, declaración responsable y comunicación", en Revista Jurídica de Navarra,
núm. 49, 2010; LOZANO CUTANDA, B., "Ley Ómnibus: silencio administrativo, declaración
responsable y comunicación previa", en Diario La Ley, núm. 7339, 2010; NOGUEIRA LÓPEZ, A., "La
termita Bolkestein", en El cronista del Estado social y democrático de derecho, núm. 22, 2011;
FUENTES LÓPEZ, M., "Luces y sombras en la incorporación de la directiva de servicios", en Revista
catalana de dret públic, núm. 42, 2011; RIVERO ORTEGA, R., "Simplificación administrativa y y
Administración electrónica: objetivos pendientes en la transposición de la directiva de servicios", en
Revista catalana de dret públic, núm. 42, 2011; MUÑOZ MACHADO, S., "Ilusiones y conflictos
derivados de la directiva de servicios", en Revista General de Derecho Administrativo, núm. 21,2009 .

${ }^{9}$ Vid. artículo 9 Directiva de Servicios, artículos 5 y 12.3 de la Ley 17/2009, de 23 de noviembre, sobre el libre acceso a las actividades de servicios y su ejercicio, y, en relación con el ámbito local, el nuevo artículo 84 bis de la Ley 7/1985, de 2 de abril, reguladora de las bases del régimen local, añadido por la Ley $2 / 2011$, de 4 de marzo, de Economía Sostenible. Este último artículo, además, contempla la posibilidad de la existencia de licencias o autorizaciones concurrentes entre una entidad local y alguna otra Administración. En este caso, cuando los entes locales tienen libertad para ordenar este ámbito concreto de actividades en sus ordenanzas, "la entidad local deberá motivar expresamente en la justificación de la necesidad de la autorización o licencia el interés general concreto que se pretende proteger y que éste no se encuentra ya cubierto mediante otra autorización ya existente". En relación con el proceso de adaptación de todo nuestro ordenamiento a estos nuevos postulados en el ámbito de las licencias locales de actividad, la disposición adicional octava de la Ley 2/2011, de 4 de marzo, de Economía Sostenible, establece un mandato para que tanto el Estado como las comunidades autónomas y los entes locales tengan ultimada la modificación de su normativa, eliminando la correspondiente exigencia de licencia local de actividad cuando no concurran las razones que permiten su pervivencia, en un plazo de tiempo determinado. Vid., al respecto, nota a pie de página número 17.

${ }^{10}$ Encontramos una definición de comunicación previa en la Ley 25/2009, de 22 de diciembre, de modificación de diversas leyes para su adaptación a la Ley sobre el libre acceso a las actividades de servicios y su ejercicio. En concreto, en su artículo 2 se modifica la Ley 30/1992, de 26 de noviembre, de Régimen Jurídico de las Administraciones Públicas y del Procedimiento Administrativo Común, añadiendo en el apartado tres el artículo 71 bis, que expresa que "se entenderá por comunicación previa aquel documento mediante el que los interesados ponen en conocimiento de la Administración Pública competente sus datos identificativos y demás requisitos exigibles para el ejercicio de un derecho o el inicio de una actividad, de acuerdo con lo establecido en el artículo 70.1". Artículo este último que regula el contenido de las solicitudes de iniciación. Aunque en este trabajo, como no podía ser de otra manera, operaremos con la concepción de comunicación previa por la que ha optado el legislador, es muy 
— En relación con el régimen de autorización, se establece, con carácter general:

1. El silencio administrativo positivo desde el momento que se indica que, a falta de respuesta en el plazo determinado, la autorización está concedida. Asimismo, se establece que se puede excepcionar esta regla y prever en una norma con rango de ley un régimen de silencio administrativo negativo cuando esté justificado por una razón imperiosa de interés general ${ }^{12}$.

\section{La validez indefinida, lo que no afectará a la posibilidad de las autoridades} competentes de revocar las autorizaciones o de suspender su actividad cuando dejen de

interesante el estudio que realiza RODRÍGUEZ FONT, M. sobre otra versión de comunicación previa que ha existido en nuestro ordenamiento, sus virtualidades y sobre la diferencia entre la comunicación previa y la declaración responsable. Vid. su capítulo "Técnicas de control en la transposición de la Directiva de servicios: Comunicación previa y declaración responsable", en Nogueira López, A. (dir.), La termita Bolkestein. Mercado único vs. Derechos ciudadanos, Thomson Reuters, Cizur Menor, 2012, pp. 82-91.

${ }^{11}$ La Ley 17/2009, de 23 de noviembre, sobre el libre acceso a las actividades de servicios y su ejercicio, define la declaración responsable como "el documento suscrito por la persona titular de una actividad empresarial o profesional en la que declara, bajo su responsabilidad, que cumple con los requisitos establecidos en la norma vigente, que dispone de la documentación que así lo acredita y que se compromete a mantener su cumplimiento durante la vigencia de la actividad”. De forma más genérica, el artículo 71 bis apartado 2 de la Ley 30/1992, de 26 de noviembre, de Régimen Jurídico de las Administraciones Públicas y del Procedimiento Administrativo Común, de acuerdo con la redacción dada por la Ley 25/2009, de 22 de diciembre, de modificación de diversas leyes para su adaptación a la Ley sobre el libre acceso a las actividades de servicios y su ejercicio, define la declaración responsable como sigue: "se entenderá por declaración responsable el documento suscrito por un interesado en el que manifiesta, bajo su responsabilidad, que cumple con los requisitos establecidos en la normativa vigente para acceder al reconocimiento de un derecho o facultad o para su ejercicio, que dispone de la documentación que así lo acredita y que se compromete a mantener su cumplimiento durante el periodo de tiempo inherente a dicho reconocimiento o ejercicio".

${ }^{12}$ Vid. artículo 13.4 de la Directiva de Servicios, artículo 6 de la Ley 17/2009, de 23 de noviembre, sobre el libre acceso a las actividades de servicios y su ejercicio, y artículo 43 de la Ley 30/1992, de 26 de noviembre, de Régimen Jurídico de las Administraciones Públicas y del Procedimiento Administrativo Común, de acuerdo con la redacción dada por la Ley 25/2009, de 22 de diciembre, de modificación de diversas leyes para su adaptación a la Ley sobre el libre acceso a las actividades de servicios y su ejercicio. En aras de impulsar las reformas normativas necesarias para ampliar el ámbito de aplicación del silencio administrativo positivo y, por ende, agilizar la actuación de las administraciones públicas, la Ley 2/2011, de 4 de marzo, de Economía Sostenible, establece un plazo desde la entrada en vigor de la Ley, de tres meses para el Gobierno del Estado y de un año para las comunidades autónomas, para que evalúen si en su ámbito normativo respectivo existen razones imperiosas de interés general que justifiquen que se mantengan los efectos desestimatorios del silencio administrativo, de acuerdo con lo que establece la nueva redacción del artículo 43 de la Ley 30/1992, de 26 de noviembre, de Régimen Jurídico de las Administraciones Públicas y del Procedimiento Administrativo Común. Esta evaluación ha de servir de base para la consiguiente reforma normativa al respecto en las Cortes Generales y en los diferentes parlamentos autonómicos, transformando el sentido del silencio administrativo en positivo cuando sea posible. Vid. artículo 40 de la Ley 2/2011, de 4 de marzo, de Economía Sostenible. De manera que, de acuerdo con lo que acabamos de exponer, la concreción del sentido del silencio está, en parte, pendiente de realizar a través de normas posteriores. Decimos en parte porque en el ámbito de la normativa estatal esta adecuación del sentido del silencio a los postulados del nuevo redactado del artículo 43 de la Ley 30/1992, de 26 de noviembre, de Régimen Jurídico de las Administraciones Públicas y del Procedimiento Administrativo Común, ya se ha realizado a través del Real Decreto-Ley 8/2011, de 1 de julio, de medidas de apoyo a los deudores hipotecarios, de control del gasto público y cancelación de deudas con empresas y autónomos contraídas por las entidades locales, de fomento de la actividad empresarial e impulso de la rehabilitación y de simplificación administrativa. 
cumplirse las condiciones que dieron lugar a la obtención de la autorización. Ahora bien, el legislador podrá limitar la duración de la autorización cuando la autorización se renueve automáticamente o solo esté sujeta al cumplimiento continuo de los requisitos, cuando el número de autorizaciones disponibles sea limitado por la escasez de recursos naturales o inequívocos impedimentos técnicos, y cuando dicha limitación esté justificada por una razón imperiosa de interés genera $1^{13}$. Esta regla general, de la validez indefinida, y algunas de las excepciones, como la limitación temporal por una razón imperiosa de interés general, también son aplicables a la comunicación y a la declaración responsable ${ }^{14}$.

3. La validez en todo el territorio estatal, salvo que haya una razón imperiosa de interés general que justifique una autorización individual para cada establecimiento. La Administración también podrá otorgar autorizaciones de prestación de servicios cuya eficacia esté limitada a una parte específica del territorio cuando esté justificado por razones de orden público, seguridad pública, salud pública o protección del medio ambiente. Se exige, para aplicar ambas excepciones, que resulte proporcionado, no discriminatorio y que esté suficientemente motivado ${ }^{15}$. Esta misma regla general y sus excepciones también se aplican a la comunicación y a la declaración responsable ${ }^{16}$.

Antes de proseguir queremos remarcar que, a pesar de que se ha hecho un esfuerzo considerable por parte de los poderes públicos para adaptar nuestro ordenamiento a los postulados de la Directiva, la fase de transposición aún no está ultimada ${ }^{17}$. A pesar de

\footnotetext{
${ }^{13}$ Vid. artículos 11 y 12 de la Directiva de Servicios y artículos 7 y 8 de la Ley 17/2009, de 23 de noviembre, sobre el libre acceso a las actividades de servicios y su ejercicio.

${ }^{14}$ En cambio, se podrá limitar la duración por renovación automática o por estar sujeta al cumplimiento continuo de los requisitos de la autorización, como ya hemos apuntado, y de la declaración responsable. Vid. artículo 7 de la Ley 17/2009, de 23 de noviembre, sobre el libre acceso a las actividades de servicios y su ejercicio.

${ }^{15}$ Vid. artículo 10 de la Directiva de Servicios y artículo 7 de la Ley 17/2009, de 23 de noviembre, sobre el libre acceso a las actividades de servicios y su ejercicio.

16 Vid. artículo 7 de la Ley 17/2009, de 23 de noviembre, sobre el libre acceso a las actividades de servicios y su ejercicio.

${ }^{17}$ Como botón de muestra, cito la disposición adicional octava de la Ley 2/2011, de 4 de marzo, de Economía Sostenible, en la que se establece que, en el plazo de seis meses desde la entrada en vigor de la Ley, el Gobierno ha de evaluar si existen razones como la protección del medio ambiente o del patrimonio histórico-artístico, la seguridad o la salud públicas, o que impliquen el uso privativo y la ocupación de bienes de dominio público que justifiquen la exigencia de licencias locales de actividad y que, además, esta exigencia resulte proporcionada para que, en el caso de que no concurran las citadas razones, se elimine, a través de la correspondiente modificación normativa, la exigencia de licencia, sin perjuicio de su sustitución por otras formas de verificación y control administrativo. A las comunidades autónomas y a las entidades locales se les da un plazo de doce meses para que, en el ámbito de sus competencias, adapten igualmente su normativa de acuerdo con el criterio acabado de exponer. Al
} 
ello, sí que disponemos de suficientes normas de transposición para entrar a trabajar en la citada materia.

\section{CUESTIONES QUE AFECTAN A LA MATERIA PROTECCIÓN DEL MEDIO AMBIENTE QUE HACE QUE LAS ACTIVIDADES CON INCIDENCIA AMBIENTAL SE PUEDAN REGIR POR UN RÉGIMEN CON ESPECIFICIDADES DIFERENCIADAS EN CADA COMUNIDAD AUTÓNOMA}

A partir de la constatación de que la legislación básica estatal de libre acceso a las actividades de servicios y su ejercicio no solo incluye en su regulación las actividades de servicios contempladas en la Directiva de Servicios, sino que también extiende sus efectos sobre las actividades de fabricación de bienes e industriales, que pueden tener una incidencia ambiental considerable, hacemos referencia a dos cuestiones que pueden explicar, en parte, la diversidad de resultados que encontramos al analizar la normativa reguladora de las actividades potencialmente lesivas para el medio ambiente de las diferentes comunidades autónomas.

respecto, el Gobierno del Estado, antes de agotar el mencionado plazo de seis meses, aprueba el Real Decreto-Ley 8/2011, de 1 de julio, de medidas de apoyo a los deudores hipotecarios, de control del gasto público y cancelación de deudas con empresas y autónomos contraídas por las entidades locales, de fomento de la actividad empresarial e impulso de la rehabilitación y de simplificación administrativa, a través del cual realiza la modificación normativa correspondiente aclarando que los enunciados contenidos en la legislación estatal que se refieren a "licencias o autorizaciones" municipales se entenderán referidos a "los distintos medios de intervención administrativa en la actividad de los ciudadanos". Esta modificación normativa permite que las comunidades autónomas determinen en su normativa el medio de intervención administrativa que consideren más adecuado para conseguir una elevada protección medioambiental. Determinación que en algunas comunidades autónomas como Canarias aún no está cerrada. Para acabar, hemos de mencionar la intervención estatal realizada a través del Real Decreto-Ley 19/2012, de 25 de mayo, de Medidas Urgentes de Liberalización del Comercio y de Determinados Servicios, que, utilizando los títulos competenciales de los apartados 1, 13, 14, 16 y 18 del artículo 149.1 de la Constitución, generaliza, a través del establecimiento de las bases y, por lo tanto, estableciendo un mínimo común denominador para todo el Estado, la eliminación de la exigencia de licencia previa de instalaciones, de funcionamiento o de actividad para ejercer actividades comerciales minoristas y prestar determinados servicios previstos en el anexo de la norma, realizados a través de establecimientos permanentes, situados en cualquier parte del territorio nacional, y cuya superficie útil de exposición y venta al público no sea superior a 300 metros cuadrados. Estas licencias que no pueden ser exigidas se han de sustituir por declaraciones responsables o comunicaciones previas. En la exposición de motivos de la norma se expresa lo siguiente: "Mediante este real decreto-ley se avanza un paso más eliminando todos los supuestos de autorización o licencia municipal previa, motivados en la protección del medio ambiente, de la seguridad o de la salud públicas, ligados a establecimientos comerciales [...]. Se considera, tras realizar el juicio de necesidad y proporcionalidad, que no son necesarios controles previos por tratarse de actividades que, por su naturaleza, por las instalaciones que requieren y por la dimensión del establecimiento, no tienen un impacto susceptible de control a través de la técnica autorizatoria". 


\section{La protección del medio ambiente y del entorno urbano como ámbito incluido en el concepto de "razón imperiosa de interés general"}

A los efectos del apartado II de este trabajo, en este epígrafe solo nos interesa destacar que, como ya ha quedado patente en la introducción de este estudio, la existencia de una "razón imperiosa de interés general" como la protección del medio ambiente ${ }^{18} \mathrm{y}$ del entorno urbano justifica y habilita al legislador para que en este ámbito excepcione las reglas generales aplicables ${ }^{19}$. Así, el legislador, en el ámbito de sus respectivas competencias, puede:

- exigir autorizaciones administrativas de acuerdo con determinados requisitos y condicionamientos;

— establecer un régimen de silencio administrativo negativo;

— determinar la validez temporal de la autorización, de los efectos de la comunicación o de la declaración responsable; y

- exigir una autorización, una comunicación o una declaración responsable individual para cada establecimiento físico del prestador. Esta cuestión es importante en el ámbito de la protección ambiental porque, cuando nos referimos a actividades potencialmente lesivas para el medio ambiente, nos estamos refiriendo a actividades que se llevan a cabo desde un establecimiento concreto ubicado en un entorno concreto.

\section{Los aspectos competenciales en materia de protección del medio ambiente}

\footnotetext{
${ }^{18}$ El reconocimiento y la consolidación del medio ambiente como "razón imperiosa de interés general" se lleva a cabo a través de la Sentencia del Tribunal de Justicia de las Comunidades Europeas de 20 de septiembre de 1988, C-302/86, caso Comisión contra Reino de Dinamarca, en la que el Tribunal afirmaba lo siguiente: "La protección del medio ambiente fue considerada por este Tribunal, en su sentencia de 7 de febrero de 1985 (Association de défense des brûleurs d'huiles usagées, 240/83, Rec.1985, p. 531), como 'uno de los objetivos esenciales de la Comunidad' que, como tal, puede justificar ciertas limitaciones al principio de la libre circulación de las mercancías. El Acta Única Europea confirma además esta apreciación. A la luz de lo expuesto, hay que hacer constar que la protección del medio ambiente constituye una exigencia imperativa que puede limitar la aplicación del artículo 30 del Tratado. [...] A este respecto, hay que recordar que en la citada sentencia de 7 de febrero de 1985 este Tribunal de Justicia precisó que las medidas adoptadas para salvaguardar el medio ambiente no deben 'sobrepasar las restricciones inevitables, justificadas por el objetivo de interés general que es la protección del medio ambiente". La cursiva es nuestra. Otra sentencia significativa sobre la aplicación de la protección del medio ambiente como razón imperiosa de interés general es la de 11 de marzo de 2010, asunto Attanasio Group Srl contra Comune di Carbognano.

19 Siempre que, además, la medida sea proporcionada, de acuerdo con los objetivos que se pretenden obtener, y no sea discriminatoria.
} 
Desde el punto de vista competencial, hemos de señalar que sobre la materia de medio ambiente rige, en el ámbito de la Unión Europea, el régimen de competencia compartida $^{20}$, en el que, como el propio nombre indica, se comparte la competencia entre la Unión Europea y los Estados miembros. Así, si la Unión Europea no utiliza su potestad ordenadora, los Estados pueden ordenar la materia de la manera que les parezca más conveniente ${ }^{21}$, pero, en el momento en que la Unión Europea regula sobre la materia, el ordenamiento de los Estados miembros se ha de adaptar a dicha regulación, prevaleciendo esta última en todo caso $^{22}$. Apuntamos, además, que, de acuerdo con el principio de autonomía institucional de la Unión Europea, cada Estado distribuye a nivel interno las diferentes funciones sobre una materia de la manera que determina su ordenamiento.

Por otro lado, recordamos que el reparto competencial en materia de protección del medio ambiente en clave de derecho interno significa que el Estado tiene la potestad para dictar la legislación básica ${ }^{23}$ sobre dicha materia y las comunidades autónomas, de manera general, la potestad de desarrollar la normativa básica ${ }^{24}$, de establecer normas adicionales de protección ${ }^{25} \mathrm{y}$ de materializar la función ejecutiva sobre esta materia ${ }^{26}$.

De acuerdo con la realidad acabada de expresar, constatamos una serie de aspectos. En primer lugar, en relación con la libertad de establecimiento ${ }^{27}$, el legislador podrá exigir,

\footnotetext{
${ }^{20}$ Artículo 4.2.e) del Tratado de Funcionamiento de la Unión Europea.

${ }^{21}$ Siempre que, evidentemente, se respeten los límites marcados por las libertades económicas establecidas en el Tratado y su interpretación jurisprudencial.

22 Artículo 2.2 del Tratado de Funcionamiento de la Unión Europea. Sobre la articulación de las competencias compartidas en general, vid. HINOJOSA MARTÍNEZ, L., El reparto de competencias entre la Unión Europea y sus Estados miembros, Tirant lo Blanch, Valencia, 2006, pp. 91 y ss.; y sobre sus especificidades en materia de medio ambiente, vid. PLAZA MARTÍN, C., Derecho ambiental de la Unión Europea, Tirant lo Blanch, Valencia, 2005, pp. 113 y ss.

23 El artículo 149.1.23 de la Constitución Española reserva a los órganos centrales del Estado la "legislación básica sobre protección del medio ambiente".

${ }^{24}$ En este sentido, la STC 156/1995, en el FJ 4. ${ }^{\circ}$, delimita las competencias autonómicas como aquellas que complementan y desarrollan la legislación básica, que en el ámbito medioambiental cumple una función de ordenación a través de mínimos.

${ }^{25}$ Según la STC 170/1989, FJ 2. ${ }^{\circ}$, el sentido de estas normas adicionales es el de "completar o reforzar los niveles de protección previstos en la legislación básica, siempre que esas medidas legales autonómicas sean compatibles, no contradigan, ignoren, reduzcan o limiten la protección establecida en la legislación básica del Estado".

${ }^{26}$ Esta función, de acuerdo con el artículo 148.1.9 de la Constitución Española, puede ser desarrollada completamente por las comunidades autónomas.

27 Recordemos la inclusión en este régimen, por parte del legislador español, de las actividades de fabricación de bienes.
} 
cuando esté justificado por una razón imperiosa de interés general, que a cada establecimiento físico de una actividad con incidencia ambiental se le aplique el mecanismo de control existente y aplicable en el territorio donde se sitúa la instalación. Esto quiere decir que a cada uno de los establecimientos que pueda tener el prestador en territorio estatal se le aplicará la normativa de la Comunidad Autónoma en la que se encuentre ubicado el establecimiento. Asimismo, también puede dejar de aplicarse la regla general en el ámbito de la libre prestación y circulación de servicios, exigiendo intervención administrativa y constriñendo la eficacia de las autorizaciones, comunicaciones o declaraciones responsables a una parte específica del territorio estatal cuando el legislador considere que está justificado por razones de orden público, seguridad pública, salud pública o protección del medio ambiente. Ambas excepcionalidades territoriales podrán aplicarse siempre que, además, la medida resulte proporcionada y no discriminatoria. En relación con los prestadores establecidos en otro Estado miembro de la Unión Europea, hemos de tener en cuenta que la primera excepción no les afecta, siempre que no pretendan instalar establecimientos físicos en territorio estatal. De manera que solo si quieren ejercer la libre prestación y circulación de servicios les puede afectar la segunda excepción ${ }^{28}$. En relación con esta cuestión queremos constatar que es perfectamente factible, y creemos además que en el ámbito objeto de estudio será lo más común, que para ejercer la libertad de establecimiento habrá que cumplir un régimen de control administrativo determinado cada vez que se quiera establecer una instalación de una misma empresa, mientras que, en cambio, en relación con el ejercicio de la libre circulación de servicios ${ }^{29}$, el régimen establecido que tendrá que cumplir la empresa será válido y operativo la mayoría de las veces para todo el territorio estatal y de la Unión Europea ${ }^{30}$. Esta última virtualidad de la libre prestación de servicios vendrá facilitada a través del sistema de ventanilla única.

\footnotetext{
${ }^{28}$ Vid. artículo 12.3 de la Ley 17/2009, de 23 de noviembre, sobre el libre acceso a las actividades de servicios y su ejercicio.

${ }^{29}$ La diferencia entre la libertad de establecimiento y la libre prestación de servicios, que se aborda en la Directiva de Servicios, está perfectamente explicada, entre otros, por FORTES MARTÍN, A., "La libertad de establecimiento de los prestadores de servicios en el mercado interior bajo el nuevo régimen de la Directiva 2006/123 de 12 de diciembre", en De la Cuadra-Salcedo Fernández del Castillo, T. (dir.), El mercado interior de servicios en la Unión Europea. Estudios sobre la Directiva 123/2006/CE relativa a los servicios en el mercado interior, Marcial Pons, Madrid, 2009, pp. 132-137, y URRUTIA LIBARONA, I., Marco jurídico del libre acceso a las actividades de servicios y su ejercicio en la Comunidad Autónoma del País Vasco, Instituto Vasco de Administración Pública, Oñate, 2010, pp. 5564.

${ }^{30}$ En este sentido, en el considerando 59 de la Directiva de Servicios se señala que "como norma general, la autorización debe dar al prestador la posibilidad de acceder a la actividad de servicios o de ejercerla en
} 
En segundo lugar, otro de los aspectos que constatamos es que la normativa de la Unión Europea ya exige que una serie de actividades con incidencia ambiental necesiten para su instalación someterse al régimen de autorización administrativa establecido ${ }^{31}$. Esta normativa se ha transpuesto, evidentemente, al ordenamiento interno y ha pasado a formar parte de la normativa básica estatal y, por lo tanto, es una normativa aplicable en todas las comunidades autónomas del Estado español ${ }^{32}$. Además, en relación con esta normativa, nuestro ordenamiento jurídico determina su prevalencia en caso de conflicto con las disposiciones de la Ley sobre libre acceso a las actividades de servicios y su ejercicio $^{33}$. Esta realidad resulta coherente con la posibilidad que establece la normativa relativa a la libre prestación de servicios de excepcionar la regla general, de no imponer a los prestadores un régimen de autorización, siempre que ello esté justificado por una razón imperiosa de interés general y no sea discriminatorio y sea una medida proporcionada. Por otro lado, no podemos olvidar que el Estado dispone de títulos competenciales horizontales $^{34}$ que han servido para incidir sobre la materia eliminando en todo el Estado la licencia previa de instalaciones, de funcionamiento o de actividad para ejercer actividades comerciales minoristas y prestar determinados servicios ${ }^{35}$ y para ordenar su sustitución por una comunicación previa o una declaración responsable a través del reciente Real Decreto-Ley 19/2012, de 25 de mayo, de Medidas Urgentes de Liberalización del Comercio y de Determinados Servicios. Esta reforma se fundamenta

todo el territorio nacional, salvo que una razón imperiosa de interés general justifique una limitación territorial. Por ejemplo, la protección del medio ambiente justifica que se exija una autorización individual para cada instalación física en el territorio nacional”.

${ }^{31}$ Vid. al respecto la Directiva 2008/1/CE del Parlamento Europeo y del Consejo, de 15 de enero de 2008, relativa a la prevención y al control integrado de la contaminación.

${ }^{32}$ Vid. sobre esta cuestión la Ley 16/2002, de 1 de julio, de Prevención y Control Integrados de la Contaminación. Señalamos que esta norma no ha quedado afectada por la Ley 25/2009, de 22 de diciembre, de modificación de diversas leyes para su adaptación a la Ley sobre el libre acceso a las actividades de servicios y su ejercicio, y que, por lo tanto, llegamos a la conclusión de que la Ley 17/2009, de 23 de noviembre, sobre el libre acceso a las actividades de servicios y su ejercicio, no modifica la Ley 16/2002, de 1 de julio, de Prevención y Control Integrados de la Contaminación.

${ }^{33}$ Así, el artículo 2.4 de la Ley 17/2009, de 23 de noviembre, sobre el libre acceso a las actividades de servicios y su ejercicio, señala lo siguiente: "En caso de conflicto entre las disposiciones de esta Ley y otras disposiciones que regulen el acceso a una determinada actividad de servicios o su ejercicio en aplicación de normativa comunitaria, prevalecerán estas últimas en aquellos aspectos expresamente previstos en la normativa comunitaria de la que traigan causa".

${ }^{34}$ Como, por ejemplo, la regulación de las condiciones básicas que garanticen la igualdad de todos los españoles en el ejercicio de los derechos y en el cumplimiento de los deberes constitucionales y el establecimiento de las bases y la coordinación de la actividad económica.

35 Todos ellos previstos en el anexo de la norma, realizados a través de establecimientos permanentes, situados en cualquier parte del territorio nacional y cuya superficie útil de exposición y venta al público no sea superior a 300 metros cuadrados. 
en la no superación, por parte de las licencias existentes hasta el momento, del juicio de necesidad y proporcionalidad para proteger el medio ambiente, la seguridad o la salud pública.

En relación con el resto de actividades con incidencia ambiental respecto a las cuales ni la normativa de la Unión Europea ni la normativa básica estatal determinan el régimen de establecimiento, queda, de acuerdo con el reparto competencial establecido en esta materia, a disposición de las comunidades autónomas la concreción del régimen aplicable dentro de las posibilidades que establece la normativa que hemos estudiado. De manera que en este ámbito, y en función de cómo se comporten las diferentes comunidades autónomas, se pueden plasmar diferentes realidades:

- optar por utilizar la declaración responsable o la comunicación para el resto de actividades con incidencia ambiental;

- optar por ampliar el régimen de autorización a otras actividades e instalaciones con incidencia ambiental;

- optar por introducir dentro del régimen de autorización el silencio administrativo negativo;

- excepcionar la regla general de la validez indefinida de los controles administrativos establecidos determinando la temporalidad de la autorización, de la comunicación y de la declaración responsable o de alguno de estos controles;

- excepcionar la regla de la validez en todo el territorio de la comunidad autónoma de la autorización, de la declaración responsable y de la comunicación en el establecimiento de actividades potencialmente lesivas para el medio ambiente.

En el caso de que el resultado concreto y real de la plasmación de estas múltiples posibilidades acabara siendo muy diverso y opuesto, se podría generar el problema que se produjera por parte de los operadores una huida, deslocalización o preferencia por establecerse en las comunidades autónomas donde el legislador hubiera sido menos exigente, donde los trámites y requerimientos fueran menos onerosos y costosos en términos de medios y de tiempo. Este fenómeno podría generar, como consecuencia, que a la larga muchas comunidades autónomas acabaran bajando sus exigencias a mínimos en este ámbito para evitar, por una parte, el agravio comparativo y, por otra, la fuga de empresas. También podría ocurrir que, ante esta perspectiva, las comunidades autónomas se posicionaran desde el principio exigiendo los mínimos requerimientos. 
Por otro lado, tampoco hay que descartar la posibilidad de que desde el inicio las comunidades autónomas se decanten por mantener su modelo de intervención medioambiental, partiendo de la base de que el grado de intervención administrativa no representa un criterio decisivo para acabar instalándose en una u otra comunidad, sino que pesan mucho más otras cuestiones como la existencia de una buena red de comunicaciones e infraestructuras, la proximidad a las materias primas o la cercanía a otras industrias complementarias que hacen que se creen sinergias favorables entre ellas. Pasemos a ver, seguidamente, cómo se han comportado las comunidades autónomas al respecto.

\section{ESTUDIO DEL COMPORTAMIENTO NORMATIVO DE LAS COMUNIDADES AUTÓNOMAS EN RELACIÓN CON LA REGULACIÓN DE LA LIBERTAD DE ESTABLECIMIENTO DE LAS ACTIVIDADES POTENCIALMENTE LESIVAS PARA EL MEDIO AMBIENTE}

En primer lugar, y para enmarcar la normativa de las comunidades autónomas en este ámbito, hemos de señalar que la transposición de la Directiva de Servicios al ordenamiento interno no ha requerido una modificación sustancial de la normativa básica estatal relativa a la materia. Es decir, la Ley 16/2002, de 1 de julio, de Prevención y Control Integrados de la Contaminación ${ }^{36}$, no ha sufrido transformaciones ni mediante la Ley 25/2009, de 22 de diciembre, de modificación de diversas leyes para su adaptación a la Ley sobre el libre acceso a las actividades de servicios y su ejercicio, ni a través de la Ley 2/2011, de 4 de marzo, de Economía Sostenible. Ha sido solamente a través del Real Decreto-Ley 8/2011, de 1 de julio, de medidas de apoyo a los deudores hipotecarios, de control del gasto público y cancelación de deudas con empresas y autónomos contraídas por las entidades locales, de fomento de la actividad empresarial e impulso de la rehabilitación y de simplificación administrativa, que la citada norma

\footnotetext{
${ }^{36}$ La disposición final sexta de la citada norma se rubrica "fundamento constitucional" y señala que "esta ley tiene la consideración de legislación básica sobre protección del medio ambiente de acuerdo con lo establecido en el artículo 149.1.23 de la Constitución".
} 
básica estatal ha sido modificada de forma poco significativa ${ }^{37}$. De entrada, hemos de recordar que la Ley de Prevención y Control Integrados de la Contaminación somete a autorización ambiental integrada la construcción, montaje, explotación o traslado, así como la modificación sustancial, de las instalaciones en las que se desarrolle alguna de las actividades relacionadas en el anejo 1 de la norma ${ }^{38}$, que son las mismas actividades en relación con las cuales la Directiva 2008/1/CE del Parlamento Europeo y del Consejo, de 15 de enero de 2008, relativa a la prevención y al control integrados de la contaminación, exige autorización. Además, esta norma estatal establece un régimen de silencio administrativo negativo ${ }^{39}$, determina la validez temporal de la autorización ${ }^{40}$ y exige una autorización para cada establecimiento físico del prestador ${ }^{41}$. Esta realidad normativa ha permanecido inalterada, a pesar de las transformaciones normativas de gran calado provocadas en nuestro ordenamiento por la transposición al ordenamiento interno de la Directiva de Servicios ${ }^{42}$, debido a que trae causa de la aplicación de normativa comunitaria que también regula el acceso de determinadas actividades y a que el legislador ha dispuesto que en caso de conflicto prevalece esta última legislación. Esto es así básicamente porque el regulador ha considerado que la protección del medio ambiente y del entorno urbano que se realiza a través de sus disposiciones justifica y habilita la existencia de excepciones a las reglas generales aplicables, y, por lo tanto, la existencia de esta "razón imperiosa de interés general" explica, asimismo, la permanencia de dicha normativa.

\footnotetext{
${ }^{37}$ En concreto, se ha modificado algún apartado de tres artículos de la norma para sustituir la referencia a la licencia municipal de actividades clasificadas por la genérica expresión "medios de intervención administrativa".

${ }^{38}$ Vid. artículos 2 y 9 de la Ley 16/2002, de 1 de julio, de Prevención y Control Integrados de la Contaminación.

${ }^{39}$ Vid. artículo 21.2 de la Ley 16/2002, de 1 de julio, de Prevención y Control Integrados de la Contaminación, donde se establece que, transcurrido el plazo máximo de diez meses sin haberse notificado resolución expresa, podrá entenderse desestimada la solicitud presentada.

${ }^{40}$ Vid. artículo 25 de la Ley 16/2002, de 1 de julio, de Prevención y Control Integrados de la Contaminación.

${ }^{41}$ La norma define instalación como "cualquier unidad técnica fija en donde se desarrolle una o más de las actividades industriales enumeradas en el anejo 1 de la presente Ley, así como cualesquiera otras actividades directamente relacionadas con aquellas que guarden relación de índole técnica con las actividades llevadas a cabo en dicho lugar y puedan tener repercusiones sobre las emisiones y la contaminación". Vid. artículo 3 c) y 9 de la Ley 16/2002, de 1 de julio, de Prevención y Control Integrados de la Contaminación.

${ }^{42}$ Han sido tales las transformaciones normativas que ha sufrido nuestro ordenamiento interno para transponer la Directiva de Servicios que podríamos considerar que nuestro ordenamiento ha sufrido un auténtico "tsunami normativo".
} 
Hemos de recordar aquí que, muy recientemente, a través del Real Decreto-Ley 19/2012, de 25 de mayo, de Medidas Urgentes de Liberalización del Comercio y de Determinados Servicios, el Estado ha liberado al comercio minorista y a determinados servicios que tengan una superficie útil no superior a 300 metros cuadrados de la exigencia de obtener licencia de actividad o licencia ambiental. De manera que por la franja baja de la incidencia ambiental se ha dejado sin margen de valoración ni maniobra a las comunidades autónomas.

A partir de esta ordenación de mínimos del ámbito objeto de estudio, materializada en la normativa mencionada, pasamos a analizar la normativa de las diferentes comunidades autónomas en relación con la regulación de la libertad de establecimiento de las actividades potencialmente lesivas para el medio ambiente ${ }^{43}$.

\section{Canarias}

Para conocer la situación de Canarias, nos parece de vital importancia analizar la Ley del Parlamento de Canarias 7/2011, de 5 de abril, de Actividades Clasificadas y Espectáculos Públicos y otras Medidas Administrativas ${ }^{44}$, que entró en vigor el 15 de octubre de $2011^{45}$. Es objeto de la Ley, entre otras cuestiones, regular el régimen jurídico y los instrumentos de intervención administrativa aplicables a la instalación y apertura de establecimientos físicos que sirven de soporte a la realización de actividades clasificadas $^{46}$. A efectos de los objetivos de este epígrafe, consideramos relevante destacar las siguientes cuestiones:

- Según la citada Ley, se consideran actividades clasificadas "aquellas que sean susceptibles de ocasionar molestias, alterar las condiciones de salubridad, causar daños al medio ambiente o producir riesgo para las personas o para las cosas, cualquiera que

\footnotetext{
${ }^{43}$ En relación con el impacto de la corriente liberalizadora sobre las actividades clasificadas, es muy revelador el trabajo de PERNAS GARCÍA, J., "El efecto desregulador de la Directiva de servicios y su incidencia en la ordenación administrativa ambiental", en Nogueira López, A. (dir.), La termita Bolkestein... cit., pp. 289-298 y 314-317.

44 El Parlamento de Canarias no ha dictado ninguna norma que desarrolle la Ley 16/2002, de 1 de julio, de Prevención y Control Integrados de la Contaminación, y, por lo tanto, se aplican el régimen de autorización ambiental integrada establecido en la norma estatal y la norma objeto de estudio en este epígrafe.

45 La disposición final tercera de la Ley establece que esta "entrará en vigor a los seis meses de su publicación en el Boletín Oficial de Canarias". Publicación realizada el 15 de abril de 2011.

${ }^{46}$ Vid. artículo 1.1.a) Ley del Parlamento de Canarias 7/2011, de 5 de abril, de Actividades Clasificadas y Espectáculos Públicos y otras Medidas Administrativas.
} 
sea la naturaleza jurídica del suelo donde se asientan" ${ }^{\natural 7}$. El Gobierno de Canarias ha de establecer mediante un decreto la relación de actividades clasificadas teniendo en cuenta que en estas se han de dar las características acabadas de mencionar ${ }^{48}, \mathrm{y}$, además, este decreto también ha de servir para determinar expresa y motivadamente aquellas actividades clasificadas que requieran, excepcionalmente, autorización administrativa previa $^{49}$ por concurrir en ellas dos circunstancias: en primer lugar, que presenten un riesgo de incidencia grave o muy grave en los factores que las caracterizan como actividades clasificadas ${ }^{50}$ por sus propias características objetivas o su emplazamiento, $\mathrm{y}$, en segundo lugar, que en el caso de que se produzca tal incidencia, los efectos negativos sean irreversibles o difícilmente reversibles ${ }^{51}$. Asimismo, la puesta en marcha de dichas actividades sujetas a licencia administrativa previa requerirá la presentación a la Administración de una declaración responsable por parte del promotor ${ }^{52}$. El régimen de licencia de actividad clasificada se caracteriza, a efectos de nuestros intereses, por otorgarse por período indefinido ${ }^{53}$, por proyectarse sobre cada infraestructura estable del prestador a partir de la cual se lleva a cabo efectivamente una determinada actividad clasificada $^{54}$ y por tener un régimen de silencio positivo cuando, o bien el informe de calificación hubiese sido favorable o condicionado al cumplimiento de determinadas medidas correctoras, operando, en este último caso, la estimación, por silencio, de la

\footnotetext{
${ }^{47}$ Vid. artículo 2.1.a) Ley del Parlamento de Canarias 7/2011, de 5 de abril, de Actividades Clasificadas y Espectáculos Públicos y otras Medidas Administrativas.

${ }^{48}$ Vid. artículo 2.2 Ley del Parlamento de Canarias 7/2011, de 5 de abril, de Actividades Clasificadas y Espectáculos Públicos y otras Medidas Administrativas.

49 Vid. artículos 13 y 5.1 Ley del Parlamento de Canarias 7/2011, de 5 de abril, de Actividades Clasificadas y Espectáculos Públicos y otras Medidas Administrativas. Aquí los términos autorización y licencia se utilizan indistintamente como sinónimos.

${ }^{50}$ Los factores que caracterizan a las actividades como clasificadas son la susceptibilidad de ocasionar molestias, alterar las condiciones de salubridad, causar daños al medio ambiente o producir riesgo para las personas o para las cosas.

${ }^{51}$ Vid. artículo 5.1 Ley del Parlamento de Canarias 7/2011, de 5 de abril, de Actividades Clasificadas y Espectáculos Públicos y otras Medidas Administrativas.

${ }^{52} \mathrm{La}$ declaración responsable ha de adjuntar la certificación técnica que acredite la realización de las obras y el acondicionamiento a las exigencias establecidas en la licencia de instalación. Vid. artículo 28 Ley del Parlamento de Canarias 7/2011, de 5 de abril, de Actividades Clasificadas y Espectáculos Públicos y otras Medidas Administrativas.

${ }^{53}$ Esta regla no nos ha de hacer perder de vista que las licencias se pueden modificar de oficio cuando concurran determinadas circunstancias, se pueden extinguir en determinados casos, pueden ser objeto de suspensión adoptada como medida provisional y caducarán ante determinadas circunstancias. Vid. artículo 15, 30, 31 y 32 Ley del Parlamento de Canarias 7/2011, de 5 de abril, de Actividades Clasificadas y Espectáculos Públicos y otras Medidas Administrativas.

${ }^{54}$ Vid. artículo 1 de la Ley del Parlamento de Canarias 7/2011, de 5 de abril, de Actividades Clasificadas y Espectáculos Públicos y otras Medidas Administrativas.
} 
solicitud condicionada al cumplimiento de las medidas impuestas en el informe, o bien, en el caso de actividades molestas, el informe de calificación no hubiere sido emitido ni notificado al interesado dentro del plazo de resolución establecido ${ }^{55}$. De todas formas, no podemos perder de vista que la regla general, relativa al régimen de intervención previa para la instalación, la apertura y la puesta en funcionamiento de los establecimientos que sirven de soporte a la realización de las actividades clasificadas, es la comunicación previa por parte del promotor ${ }^{56}$.

- Mientras no entre en vigor la citada normativa reglamentaria, se considerarán actividades clasificadas las incluidas en el nomenclátor anejo al Reglamento de Actividades Molestas, Insalubres, Nocivas y Peligrosas, aprobado por Decreto 2414/1961, de 30 de noviembre, así como cualesquiera otras actividades de efectos similares a estas que sean susceptibles de ocasionar molestias, alterar las condiciones de salubridad, causar daños al medio ambiente o producir riesgo para las personas o para las cosas, y se aplicará el régimen de la licencia de actividad clasificada para la instalación, el traslado y la modificación sustancial, explicado ut supra, como régimen de intervención previa aplicable a todas las actividades ${ }^{57}$.

- En las actividades que requieran autorización ambiental integrada y en las autorizaciones sectoriales que estén precedidas de evaluación medioambiental, la norma, para canalizar la competencia administrativa local objeto de estudio y a la vez coordinar la actuación administrativa en sede de protección del medio ambiente y del entorno urbano, aporta la solución de excluir la licencia municipal expresa, considerando implícita dicha licencia en la resolución de autorización ambiental integrada y en la autorización sectorial precedida de evaluación medioambiental, ejerciendo el municipio dicha competencia al emitir un informe municipal previo y preceptivo que se evacuará en el procedimiento correspondiente ${ }^{58}$.

\footnotetext{
${ }^{55}$ En el resto de supuestos, el transcurso del plazo para resolver y notificar la resolución faculta al interesado para entender desestimada la solicitud. Vid. artículo 24 Ley del Parlamento de Canarias 7/2011, de 5 de abril, de Actividades Clasificadas y Espectáculos Públicos y otras Medidas Administrativas. En el caso de las actividades clasificadas sujetas a evaluación de impacto ambiental, el régimen del acto presunto se regula en el artículo 27 de la misma Ley.

${ }^{56}$ Vid. artículo 5.1 Ley del Parlamento de Canarias 7/2011, de 5 de abril, de Actividades Clasificadas y Espectáculos Públicos y otras Medidas Administrativas.

${ }^{57}$ Vid. artículo 13 y disposición transitoria cuarta Ley del Parlamento de Canarias 7/2011, de 5 de abril, de Actividades Clasificadas y Espectáculos Públicos y otras Medidas Administrativas.

${ }^{58}$ Vid. apartado 2c) de la exposición de motivos y artículo 6 Ley del Parlamento de Canarias 7/2011, de 5 de abril, de Actividades Clasificadas y Espectáculos Públicos y otras Medidas Administrativas. Nosotros
} 
De acuerdo con todo lo expuesto hasta el momento, para conocer de manera completa cómo la Comunidad Autónoma de Canarias acaba diseñando la intervención administrativa local sobre las actividades potencialmente lesivas sobre el medio ambiente, tendremos que esperar a que se apruebe el Decreto que ha de acabar de determinar de manera concreta aquellas actividades clasificadas que excepcionalmente requieran licencia local previa. Si el Decreto no se aprueba ${ }^{59}$, el régimen transitorio previsto es el de la generalización de la licencia de actividad clasificada a todas las actividades incluidas en el nomenclátor anejo al reglamento de actividades clasificadas. En caso de que el Decreto se acabe aprobando, la normativa canaria prevé que el régimen general para la instalación y la puesta en marcha sea la comunicación previa, y el régimen excepcional, la licencia administrativa previa para la instalación y la declaración responsable para la puesta en marcha.

\section{Aragón}

Para el estudio del régimen de establecimiento de las actividades con incidencia ambiental en Aragón, hemos de hacer referencia a la Ley 7/2006, de 22 de junio, de Protección Ambiental de Aragón, que tiene como objeto regular el sistema de intervención administrativa ambiental de los planes, los programas, los proyectos, las instalaciones y las actividades susceptibles de afectar al medio ambiente en el territorio de Aragón como forma de prevención, reducción y control de la contaminación y del impacto ambiental ${ }^{60}$.

Esta misma norma, en la disposición adicional sexta, establece la inaplicabilidad del Reglamento de Actividades Molestas, Insalubres, Nocivas y Peligrosas en la Comunidad Autónoma de Aragón. Al respecto, la nueva regulación establece, para las actividades sometidas a autorización ambiental integrada, la integración de la competencia local en esta materia en el procedimiento de otorgamiento de la

creemos que este informe debería tener carácter vinculante en relación con las cuestiones que son competencia municipal cuando se pronuncie de manera desfavorable o imponga medidas preventivas, de control o de garantía. De esta manera se garantiza el ejercicio de las competencias municipales en este ámbito.

${ }^{59}$ En fecha 30 de mayo de 2012 aún no había rastro del Decreto que ha de implementar el verdadero cambio sustantivo en la normativa canaria.

${ }^{60}$ Vid. artículo 1 Ley 7/2006, de 22 de junio, de Protección Ambiental de Aragón. 
autorización ambiental integrada ${ }^{61}, y$, para las actividades sometidas a licencia ambiental de actividades clasificadas, la norma citada establece una nueva regulación que desplaza a la antigua.

Con el ánimo de conocer cómo se ha regulado desde la Comunidad Autónoma de Aragón la intervención administrativa en el establecimiento de las actividades con incidencia ambiental, destacamos los siguientes aspectos:

- Aparte de las actividades sometidas a autorización ambiental integrada, que son las que recoge la normativa básica estatal y que siguen el régimen jurídico básico apuntado ut supra ${ }^{62}$, la norma objeto de estudio regula un régimen de licencia ambiental de actividades clasificadas al que se ha de someter la construcción, montaje, explotación, traslado o modificación sustancial de las actividades clasificadas de titularidad pública o privada $^{63}$. Para determinar estas actividades, el legislador aragonés no ha optado por una lista enumerativa que, además, tampoco podría ser un númerus clausus, sino que ha preferido utilizar un sistema de cláusula o fórmula general que, por otro lado, respeta el espíritu del Reglamento de actividades clasificadas, ahora desplazado en su aplicación ${ }^{64}$. En cambio, sí que el legislador ha recurrido a la lista enumerativa para determinar aquellas actividades que no tienen la consideración de actividades clasificadas ${ }^{65}$ y cuyo control se considera que queda suficientemente garantizado a través de la licencia de apertura de actividades no clasificadas regulada en la legislación autonómica de régimen local $^{66}$. De manera que, por arriba, no se someten al régimen de licencia ambiental de actividades clasificadas las actividades sujetas a autorización ambiental integrada $\mathrm{y}$, por abajo, no se someten a este régimen las actividades excluidas

\footnotetext{
${ }^{61}$ En este sentido, el artículo 54 de la Ley 7/2006, de 22 de junio, de Protección Ambiental de Aragón, determina que "el procedimiento para el otorgamiento de la autorización ambiental integrada sustituirá al procedimiento para el otorgamiento de la licencia ambiental de actividades clasificadas, evacuándose en tal caso el informe municipal previo, preceptivo y vinculante, sobre la adecuación de la instalación a tal fin".

${ }^{62}$ Vid., entre otros, los artículos 40, 49, 51 y 56, anexo VI de la Ley 7/2006, de 22 de junio, de Protección Ambiental de Aragón.

${ }^{63}$ Vid. el artículo 60.1 de la Ley 7/2006, de 22 de junio, de Protección Ambiental de Aragón.

${ }^{64}$ Vid. el artículo 60.2 de la Ley 7/2006, de 22 de junio, de Protección Ambiental de Aragón.

${ }^{65}$ Vid. anexo VII de la Ley 7/2006, de 22 de junio, de Protección Ambiental de Aragón, modificado por el Decreto 74/2011, de 22 de marzo, que eleva el umbral de la potencia instalada para que un mayor número de actividades queden excluidas de licencia por su escasa incidencia ambiental. De manera que para el resto de actividades queda justificada la exigencia de licencia ambiental por la razón imperiosa de interés general de protección del medio ambiente y del entorno urbano, y, por lo tanto, este cambio significa una adaptación a los postulados de la Directiva de Servicios.

${ }^{66}$ Vid. el artículo 60.3 de la Ley 7/2006, de 22 de junio, de Protección Ambiental de Aragón.
} 
expresamente por considerarse que no afectan suficientemente al medio ambiente y urbano como para estar clasificadas.

- A los efectos de los objetivos de este trabajo, nos interesa destacar que el régimen de licencia ambiental de actividades clasificadas significa que toda persona física o jurídica que pretenda desarrollar una actividad clasificada o realizar una modificación sustancial deberá solicitar la licencia con carácter previo ante el ayuntamiento correspondiente del término municipal en que se ubique la instalación en la que se va a desarrollar la $\operatorname{actividad}^{67}$. El plazo máximo que tiene la Administración para resolver y notificar al interesado es de cuatro meses, transcurrido el cual podrá entenderse estimada la solicitud presentada siempre que se haya emitido un informe favorable de calificación de la actividad $^{68}$. En principio, la licencia de actividades clasificadas se otorga con carácter indefinido ${ }^{69}$.

- Finalmente, la norma aragonesa establece que, con carácter previo al comienzo de las actividades, tanto las actividades sujetas a autorización ambiental integrada como las actividades sujetas a licencia ambiental de actividades clasificadas han de obtener la licencia de inicio de actividad ${ }^{70}$ con el objetivo de que la Administración competente compruebe que las instalaciones realizadas se ajustan al proyecto aprobado, a las medidas correctoras y al condicionado impuestos en la autorización ambiental integrada o en la licencia ambiental de actividades clasificadas. Dicha licencia se ha de solicitar ante el ayuntamiento correspondiente $\mathrm{y}$, transcurrido el plazo de resolución $\mathrm{y}$ notificación sin haberse notificado la resolución, podrá entenderse estimada la solicitud presentada $^{71}$. Aunque la norma tampoco diga nada al respecto, consideramos que esta licencia también se otorga con carácter indefinido mientras la actividad se encuentre en funcionamiento $^{72}$.

En función de cómo se materialice el acta de comprobación de la actividad por la Administración competente en el procedimiento de obtención de la licencia de inicio de

\footnotetext{
${ }^{67}$ Vid. el artículo 64 de la Ley 7/2006, de 22 de junio, de Protección Ambiental de Aragón.

${ }^{68}$ Vid. el artículo 67 de la Ley 7/2006, de 22 de junio, de Protección Ambiental de Aragón.

${ }^{69}$ La norma objeto de estudio no establece ningún período de validez de la licencia ni la necesidad de proceder a su renovación.

${ }^{70}$ Vid. el artículo 72 de la Ley 7/2006, de 22 de junio, de Protección Ambiental de Aragón.

${ }^{71}$ Vid. el artículo 74 de la Ley 7/2006, de 22 de junio, de Protección Ambiental de Aragón.

${ }^{72}$ Esta consideración la hacemos en coherencia con el objetivo que se persigue con su existencia.
} 
actividad, nosotros consideramos que dicha licencia podría ser sustituida perfectamente por una declaración responsable o por una comunicación previa del titular de la actividad a la Administración. En dicha declaración el titular tendría que manifestar que dispone de un certificado del técnico director de la ejecución en el que se especifica la conformidad de la instalación o actividad a la autorización ambiental o a la licencia ambiental de actividades clasificadas, o de un certificado emitido por un organismo de control autorizado en el que se acredita el cumplimiento de las condiciones impuestas en la autorización ambiental integrada o en la licencia ambiental de actividades clasificadas $^{73}$. De esta manera, la norma objeto de estudio se ajustaría más a los postulados de la Ley básica 17/2009, de 23 de noviembre, sobre el libre acceso a las actividades de servicios y su ejercicio. También consideramos que para conseguir dicha convergencia sería aconsejable que las actividades excluidas de la licencia ambiental de actividades clasificadas no se sometieran a una licencia de apertura, sino que se estableciera un régimen de comunicación o declaración responsable.

En relación con las observaciones que acabamos de realizar, la Ley 7/2006, de 22 de junio, de Protección Ambiental de Aragón, ha sufrido una modificación a través de la Ley 3/2012, de 8 de marzo, de Medidas Fiscales y Administrativas de la Comunidad Autónoma de Aragón, pero con el objetivo de agilizar la actividad económica, estableciendo la posibilidad de que algunas actividades sujetas a licencia ambiental de actividades clasificadas ${ }^{74}$ puedan iniciarse utilizando el instrumento de una declaración responsable del titular de la actividad sin perjuicio de la obligación de obtener la licencia presentando en el plazo de tres meses la solicitud correspondiente. El problema está en que, según el redactado, no queda claro si esta posibilidad de utilizar la declaración responsable se refiere a la licencia ambiental de actividades clasificadas o a la licencia de inicio de actividad. Por la ubicación del precepto, parece que se refiera a la primera hipótesis, pero por la literalidad y la secuencialidad de las licencias, parece referirse a la segunda hipótesis.

\section{Cantabria}

\footnotetext{
${ }^{73}$ Certificado que ya se exige en la documentación que se ha de presentar al ayuntamiento junto con la solicitud de la licencia de inicio de actividad.

${ }^{74} \mathrm{Se}$ refiere a aquellas actividades que no requieran de determinadas autorizaciones sectoriales que se especifican en el apartado 5 del artículo 60 de la Ley 7/2006.
} 
En el ámbito de la Comunidad Autónoma de Cantabria hemos de analizar la Ley 17/2006, de 11 de diciembre, de Control Ambiental Integrado de Cantabria. En esta norma se regula el régimen de autorización ambiental integrada al que se han de someter las instalaciones y actividades relacionadas en el anexo A -que son las mismas que aparecen en el anejo 1 de la Ley 16/2002, de 1 de julio, de Prevención y Control Integrados de la Contaminación-. Asimismo, se ordenan la evaluación ambiental de planes y programas y la evaluación de impacto ambiental de proyectos, actividades o instalaciones.

Además, la norma somete un número muy amplio y diverso de actividades, referenciadas en el anexo $\mathrm{C}$, a una técnica de control ambiental denominada “comprobación ambiental”, que es competencia de la Administración de la Comunidad Autónoma de Cantabria ${ }^{75}$. Esta técnica se incardina en el procedimiento de una licencia municipal de apertura o actividad y consta de una serie de trámites de comprobación y evaluación de la incidencia ambiental de la actividad que han de servir para determinar las condiciones de prevención y protección ambiental a las que deben sujetarse cualesquiera instalaciones o actividades que puedan ser causa de molestias, riesgos o daños para las personas, sus bienes o el ambiente ${ }^{76}$. Estas condiciones de prevención y protección ambiental se incluirán en las determinaciones de las licencias de actividad y apertura. De hecho, estas condiciones a las que nos referimos se establecen por la Comisión para la Comprobación Ambiental en un informe, llamado de "comprobación ambiental", que se remite al ayuntamiento correspondiente con carácter previo al otorgamiento de la licencia solicitada. Este informe es vinculante para el ayuntamiento cuando implica la denegación de la licencia municipal o la imposición de medidas correctoras. La Comisión tiene un mes para emitir su informe. Si la Comisión supera este plazo sin haber emitido el informe, se puede proseguir con las actuaciones. Ahora

\footnotetext{
${ }^{75}$ Las actividades que se enumeran en el anexo $\mathrm{C}$ se han de someter, en todo caso, a la técnica de control ambiental denominada "comprobación ambiental". Pero es que, de acuerdo con el principio de que será objeto de comprobación toda actividad que potencialmente afecte al medio ambiente, la norma permite que las ordenanzas municipales establezcan normas adicionales de protección y que, por lo tanto, se extienda la obligatoriedad de someter otras actividades a esta técnica.

76 Vid. apartados 1 y 4 del artículo 31de la Ley 17/2006, de 11 de diciembre, de Control Ambiental Integrado de Cantabria. Como apuntan los apartados 1 y 3 del artículo 32 de la citada norma: "[...] la finalidad de la comprobación ambiental es prevenir o reducir en origen la producción de residuos y la emisión de sustancias contaminantes al aire, al agua o al suelo, así como la generación de molestias o de riesgos que produzcan las correspondientes actividades e instalaciones y que sean susceptibles de afectar a las personas, bienes o al medio ambiente. [...] Particularmente, la comprobación establecerá las condiciones necesarias para la protección de las personas y sus bienes, así como del medio ambiente, y las medidas preventivas de control que sean procedentes".
} 
bien, si el informe se emite fuera de plazo pero antes de la resolución municipal, esta resolución ha de tener en cuenta el citado informe ${ }^{77}$.

Las actividades del anexo $\mathrm{C}$, una vez que han obtenido la licencia municipal de apertura o actividad, que incorpora la correspondiente "comprobación ambiental", y antes de su puesta en funcionamiento, se han de someter a una serie de verificaciones. Una, realizada por el técnico director de la ejecución del proyecto, consta de la expedición de una certificación según la cual la instalación se adecua a la licencia otorgada. La otra se basa en la comprobación, realizada por los servicios administrativos, de la efectividad de las medidas correctoras exigidas. La realización de esta última verificación se acreditará mediante acta levantada al efecto ${ }^{78}$. La presentación de ambos certificados conlleva la inscripción de oficio en los oportunos registros ambientales y habilita para ejercer la actividad $^{79}$. Además, todas estas actividades sometidas a la técnica de la “comprobación ambiental” también están sujetas a controles periódicos. Todos estos controles, tanto los iniciales como los periódicos, han de servir para garantizar que estas actividades estén, de forma permanente y constante, adecuadas a las prescripciones legales y a las determinaciones contenidas en el informe de "comprobación ambiental" ${ }^{\prime 80}$.

Esta técnica de la "comprobación ambiental" supondría una cláusula de cierre del sistema mediante la cual las actividades que hayan quedado fuera de las otras técnicas ambientales mencionadas y puedan afectar al medio ambiente, aunque sea de manera indirecta, se tendrían que someter a esta "comprobación ambiental" 81 . Con esta última técnica se completaría así la tarea de sustitución del Reglamento de Actividades Molestas, Insalubres, Nocivas y Peligrosas de 1961, que, de acuerdo con la disposición adicional tercera, dejará de ser de aplicación directa en el ámbito territorial de la Comunidad Autónoma de Cantabria.

\footnotetext{
${ }^{77}$ Vid. apartados 1, 4 y 5 del artículo 37 de la Ley 17/2006, de 11 de diciembre, de Control Ambiental Integrado de Cantabria.

${ }^{78}$ Vid. artículo 39 de la Ley 17/2006, de 11 de diciembre, de Control Ambiental Integrado de Cantabria.

${ }^{79}$ Vid. artículo 40 de la Ley 17/2006, de 11 de diciembre, de Control Ambiental Integrado de Cantabria.

${ }^{80}$ Vid. artículo 38 de la Ley 17/2006, de 11 de diciembre, de Control Ambiental Integrado de Cantabria

${ }^{81}$ En este sentido se pronuncia el artículo 8.3 de la Ley 17/2006, de 11 de diciembre, de Control Ambiental Integrado de Cantabria cuando expresa lo siguiente: "[...] las instalaciones o actividades que puedan tener incidencia ambiental significativa, excepto las comprendidas en los anexos A y B de la presente Ley, se sujetarán a la comprobación ambiental [...]. En particular, y a los efectos anteriores, se considera que las actividades e instalaciones enumeradas en el anexo $\mathrm{C}$ de esta Ley tienen incidencia significativa, sin que esta enumeración tenga carácter limitativo".
} 
La norma utiliza como criterio que articula el régimen de protección de la legalidad ambiental el de la invalidez de las autorizaciones o licencias que se hayan expedido sin la efectuación preceptiva de la técnica de control ambiental correspondiente, léase autorización ambiental integrada, evaluación de impacto ambiental o comprobación ambiental $^{82}$.

Nosotros consideramos que, de acuerdo con la normativa relativa a la libertad de establecimiento de las actividades de servicios, hay una serie de actividades del anexo C, como bares, cafeterías, bodegas, snack-bar, degustación de café, bocaterías, entre otras, que, además, representan un tanto por ciento muy elevado del número total de licencias, en relación con las cuales no está justificada la utilización de un instrumento de intervención como la licencia municipal de actividad, en el que se incardina la técnica de control ambiental llamada comprobación ambiental, y sobre las que postulamos que se tendrían que emplear figuras menos onerosas como la comunicación previa o la declaración responsable ${ }^{83}$.

\section{Murcia}

Para conocer el modelo de intervención administrativa sobre las actividades potencialmente lesivas para el medio ambiente en la Comunidad Autónoma de la Región de Murcia, hemos de estudiar la Ley 4/2009, de 14 de mayo, de Protección Ambiental Integrada. Al analizar la norma nos ha sorprendido, teniendo en cuenta la fecha de entrada en vigor de la Directiva de Servicios y su fecha límite de transposición (28 de diciembre de 2009), en relación con la fecha de aprobación de la norma objeto de estudio, que en la exposición de motivos no apareciera en ningún momento una mención a la necesidad de dar cumplimiento a las exigencias formales y materiales derivadas de la Directiva de Servicios.

En esta norma de la Región de Murcia se distinguen diferentes niveles de intervención:

\footnotetext{
${ }^{82}$ Vid. artículo 10 de la Ley 17/2006, de 11 de diciembre, de Control Ambiental Integrado de Cantabria.

${ }^{83}$ Es verdad que la norma cántabra analizada ha sufrido unos cambios menores que traen causa de la Ley 5/2011, de 29 de diciembre, de Medidas Fiscales y Administrativas, y que a los efectos de nuestro trabajo esta permite que a través de un decreto se modifiquen los anexos no solo para adecuarlos al progreso y al estado de la técnica, sino también, cuando sea necesario, para lograr una más eficaz protección del medio ambiente. Esta modificada disposición final primera, a pesar de su literalidad, se podría utilizar en un futuro para reducir el número de actividades incluidas en el anexo C. Estaremos atentos para ver cómo se utiliza esta posibilidad en el futuro.
} 
- En primer lugar, las autorizaciones ambientales autonómicas, dentro de las cuales se ha de diferenciar entre la autorización ambiental integrada ${ }^{84}$ y la autorización ambiental única $^{85}$. Se agrupan ambas como autorizaciones ambientales autonómicas porque sobre ellas resuelve la Administración autonómica. Dicho esto, no podemos olvidar que en ambas autorizaciones queda integrado el procedimiento de la licencia municipal de $\operatorname{actividad}^{86}$ a través de un procedimiento que integra la participación de los ayuntamientos mediante un control urbanístico previo e informando sobre los aspectos de su competencia. El comienzo de la explotación de las instalaciones sometidas a autorización ambiental autonómica se comunica previamente al órgano autonómico competente y al ayuntamiento adjuntando un informe de una entidad de control ambiental. En relación con la autorización ambiental única, el plazo máximo para resolver y notificar se establece en ocho meses, transcurrido el cual sin que la Administración haya notificado resolución expresa se entenderá la solicitud como desestimada $^{87}$. Se fija en este caso, también, una validez temporal máxima de ocho $\operatorname{años}^{88}$.

- En segundo lugar, las actividades sujetas solamente a licencia municipal de actividad, en cuyo procedimiento se ha de realizar un informe de calificación ambiental de la actividad y se integran las diferentes autorizaciones municipales con fines ambientales, como el vertido de alcantarillado. El informe de calificación ambiental tiene por objeto verificar la adecuación de las prescripciones contenidas en el proyecto técnico, la memoria ambiental y el resto de la documentación aportada en la solicitud a

\footnotetext{
84 A autorización ambiental integrada se someten las mismas actividades previstas en la Ley estatal 16/2002, de 18 de julio, de Prevención y Control Integrados de la Contaminación.

${ }^{85}$ A autorización ambiental única se someten todas aquellas actividades diferentes de las que se someten a autorización ambiental integrada a las que la legislación básica sujeta a evaluación de impacto ambiental o a una autorización ambiental específica (de residuos, vertidos al mar o emisiones a la atmósfera). En relación con la autorización ambiental única, es importante dejar claro que no se trata de una nueva autorización que se sume a las que se exigen, sino que estamos ante un mecanismo de simplificación formal que sirve para aglutinar todos los requerimientos y autorizaciones en una única autorización.

${ }^{86}$ Según el artículo 59.2 de la Ley 4/2009, de 14 de mayo, de Protección Ambiental Integrada de la Región de Murcia, la licencia de actividad tiene por objeto verificar si el local, instalación o espacio reúne las condiciones ambientales, de seguridad y salubridad y cumple las restantes normas técnicas establecidas en las ordenanzas y en la normativa sectorial correspondiente.

${ }^{87}$ A contar desde la fecha en que la solicitud haya tenido entrada en el registro del órgano competente. Vid. artículo 52 de la Ley 4/2009, de 14 de mayo, de Protección Ambiental Integrada de la Región de Murcia.

${ }^{88}$ Se puede establecer un período inferior en función de las condiciones de la instalación. Vid. artículo 55 de la Ley 4/2009, de 14 de mayo, de Protección Ambiental Integrada de la Región de Murcia.
} 
las disposiciones contenidas en la norma objeto de estudio y en la legislación ambiental aplicable, y propone el programa de vigilancia ambiental. En el caso de estas actividades, el plazo máximo que tiene la Administración para resolver y notificar la resolución de otorgamiento o denegación de licencia es de seis meses, transcurrido el cual sin que la Administración haya notificado la resolución, se entenderá la solicitud como estimada $^{89}$. La vigencia de dicha licencia se establece como indefinida ${ }^{90}$. Independientemente de este principio, la Administración tiene la potestad de modificar de oficio la citada licencia ${ }^{91}$.

- En tercer término, tenemos las actividades inocuas y exentas de calificación ambiental, relacionadas en el anexo II de la norma. Se considera que no cabe esperar que estas actividades tengan una incidencia significativa en el medio ambiente, la seguridad o la salud de las personas, y, por ello, la norma permite que los ayuntamientos puedan sustituir en sus ordenanzas la licencia de actividad por una comunicación previa que habilitaría directamente para empezar la actividad. En el caso de que los ayuntamientos no prevean en sus ordenanzas tal sustitución, desarrollarán el procedimiento de licencia de actividad aplicable a las actividades exentas, que ha de tener un plazo máximo para resolver y notificar la resolución de la solicitud de tres meses, transcurridos los cuales la licencia se entenderá concedida por silencio administrativo positivo. Además, las ordenanzas han de establecer la duración indefinida de la licencia de actividad exenta de calificación ambiental ${ }^{92}$. En este supuesto, la Administración también tiene la potestad de modificar de oficio la citada licencia ${ }^{93}$.

\footnotetext{
${ }^{89}$ Vid. artículo 80 de la Ley 4/2009, de 14 de mayo, de Protección Ambiental Integrada de la Región de Murcia.

${ }^{90}$ Sin perjuicio de las limitaciones temporales que pueda imponer la legislación o el planeamiento urbanístico cuando se trate de usos provisionales. Vid. artículo 82 de la Ley 4/2009, de 14 de mayo, de Protección Ambiental Integrada de la Región de Murcia.

${ }^{91}$ Esta posibilidad se dará cuando las circunstancias que motivaron el otorgamiento de la licencia se hubieran alterado o sobrevinieran otras que, de haber existido anteriormente, habrían justificado su denegación o el otorgamiento en términos distintos. Vid. artículo 68 de la Ley 4/2009, de 14 de mayo, de Protección Ambiental Integrada de la Región de Murcia.

${ }^{92}$ Vid. artículo 63 de la Ley 4/2009, de 14 de mayo, de Protección Ambiental Integrada de la Región de Murcia.

${ }^{93}$ Vid. artículo 68 de la Ley 4/2009, de 14 de mayo, de Protección Ambiental Integrada de la Región de Murcia.
} 
- Por último, se establece que existen una serie de actividades que no están sujetas a licencia de actividad $^{94}$.

Por todo lo dicho hasta el momento, vemos que la normativa de la Región de Murcia ha determinado que todas las actividades potencialmente lesivas para el medio ambiente pueden estar sujetas a licencia de actividad. Por tanto, consideramos que las actividades no sujetas por la normativa a licencia de actividad son actividades que no tienen un potencial lesivo para el medio ambiente. Solo en el caso de las actividades exentas de calificación ambiental, del anexo II, los ayuntamientos, si lo consideran conveniente, pueden sustituir la licencia de actividad por el mecanismo de la comunicación previa. En relación con esta disposición, nosotros consideramos que la normativa autonómica tendría que haber establecido de manera general que todas las actividades del anexo II se rijan por el régimen de la comunicación previa. Esta posición la defendemos porque la licencia municipal de actividad no es un mecanismo proporcional para actividades con escasísima o nula incidencia ambiental.

\section{Navarra}

La Comunidad Foral de Navarra contiene la regulación de la intervención administrativa sobre las actividades susceptibles de alterar las condiciones del medio ambiente o de producir riesgos para el medio ambiente o la seguridad o salud de las personas y sus bienes en la Ley foral 4/2005, de 22 de marzo, de Intervención para la Protección Ambiental de Navarra. Esta norma, como veremos, diseña, en el régimen de establecimiento de las actividades, una intervención administrativa generosa que va más allá de las exigencias ambientales determinadas a nivel de la Unión Europea. De manera que el legislador navarro ha considerado que la "razón imperiosa de interés general" protección del medio ambiente y del entorno urbano ha justificado y justifica la utilización de una serie de técnicas autorizatorias de derecho administrativo. Pasamos a ver, seguidamente, cómo se ha articulado el régimen de establecimiento en este ámbito y si este es proporcionado y no discriminatorio.

\footnotetext{
${ }^{94}$ El artículo 59.1 establece que "se exigirá licencia de actividad para la instalación, montaje, ejercicio o explotación, traslado o modificación sustancial de cualquier actividad mercantil o industrial que se pretenda desarrollar, ya sea de titularidad pública o privada, tanto en el interior de edificaciones como en espacios libres, tenga o no finalidad lucrativa".
} 
La Ley objeto de estudio determina el régimen de establecimiento de las distintas actividades en función del anejo en que se encuentran ubicadas. La Comunidad foral es competente para resolver en relación con la autorización ambiental integrada ${ }^{95}$ y la autorización de afectaciones ambientales ${ }^{96}$, sin perjuicio de la integración en ambos procedimientos de la intervención de los municipios afectados en relación con sus competencias y de la evaluación de impacto ambiental si es procedente. En relación con la autorización de afectaciones ambientales, que se aplica a las actividades que se realizan en suelo no urbanizable y que no están sometidas a otra autorización, el plazo de resolución y notificación es de cuatro meses desde la presentación de la solicitud. Si en este plazo la Administración no resuelve y notifica, se entiende la solicitud como desestimada $^{97}$.

Los ayuntamientos, por otro lado, son competentes para resolver en relación con la licencia municipal de actividades clasificadas en cuyo procedimiento se integran la evaluación de impacto ambiental y la intervención de diferentes departamentos de la Comunidad foral cuando sea procedente ${ }^{98}$. El plazo de resolución y notificación de la licencia municipal de actividades clasificadas es de cuatro meses desde la presentación de la solicitud. Si en este plazo el ayuntamiento no resuelve y notifica, se entenderá la solicitud como desestimada.

Además, tanto en el caso de las autorizaciones autonómicas como en el supuesto de la licencia municipal de actividades clasificadas, la normativa exige permisos de apertura, que se han de obtener con carácter previo al inicio de la actividad, con el objeto de comprobar que la actividad o instalación se ajusta al proyecto aprobado. En el primer caso, este permiso se denomina autorización de apertura y, en el segundo caso, licencia municipal de apertura. En ambos supuestos se establece un mes desde la presentación de la solicitud como plazo de resolución y notificación, y si en este plazo no existe respuesta, se entenderá que el permiso se otorga por silencio positivo.

\footnotetext{
${ }^{95}$ Vid. anejo 2. A y B de la Ley foral.

${ }^{96}$ Vid. anejo 2.C de la Ley foral.

97 Hemos de tener en cuenta que la normativa establece que si el promotor de la actividad es la Administración foral $\mathrm{u}$ organismos dependientes o vinculados a ella, no se exige una autorización, sino solo un informe previo y preceptivo sobre afectaciones ambientales del Departamento de Medio Ambiente, Ordenación del Territorio y Vivienda. Este informe deberá ser evacuado en el plazo de dos meses. Transcurrido este plazo sin haberse evacuado el informe, se entenderá favorable. Vid. artículo 45 de la Ley foral.

${ }^{98}$ Vid. anejo 4 de la Ley foral.
} 
Por todo lo visto en este estudio, podemos concluir que la Ley foral contempla una muy intensiva intervención de la Administración en el régimen de establecimiento de las actividades susceptibles de alterar las condiciones del medio ambiente. Realizamos esta afirmación porque, por una parte, la norma extiende la necesidad de autorización o licencia a una gran cantidad de actividades, sin que se haga referencia directa a actividades inocuas, a actividades exentas o a actividades que se someten al régimen de declaración responsable o comunicación previa, y, por otra, la intensidad de la intervención es tal que no solo existen medidas de control ambiental previo y preventivo para aprobar los respectivos proyectos de actividad bajo determinadas condiciones de sostenibilidad y protección ambiental, sino que, además, se exige que, antes de la puesta en marcha de la actividad, el promotor solicite una nueva autorización o licencia sin la cual, en el caso de la autorización de apertura, no puede conectarse a los suministros básicos de abastecimiento de agua, electricidad, etc. En relación con esta última exigencia, nos atrevemos a decir, de manera clara, que no vemos de ninguna manera que estemos ante una medida proporcionada. Es decir, para conseguir el objetivo que se pretende sería suficiente y adecuado utilizar la técnica de la declaración responsable o la de la comunicación previa, acompañadas de la presentación de la documentación que acredite que la actividad se ha realizado de acuerdo y bajo los condicionantes de los permisos otorgados.

\section{Castilla y León}

La intervención administrativa de prevención y control integrado de la contaminación sobre "las actividades, instalaciones o proyectos, de titularidad pública o privada, susceptibles de ocasionar molestias significativas, alterar las condiciones de salubridad, causar daños al medio ambiente o producir riesgos para las personas o bienes" ${ }^{\prime 99}$ se regula en Castilla y León, principalmente, a través de la Ley 11/2003, de 8 de abril, de Prevención Ambiental de Castilla y León. Esta norma establece tres regímenes de intervención diferenciados que se proyectan sobre distintos grupos de actividades e instalaciones.

\footnotetext{
${ }^{99}$ Vid. artículo 3 de la Ley 11/2003, de 8 de abril, de Prevención Ambiental de Castilla y León, que se rubrica "ámbito de aplicación".
} 
El régimen de autorización ambiental es un procedimiento que se desarrolla en sede autonómica con la actuación integrada de los ayuntamientos afectados ${ }^{100} \mathrm{y}$ de otras administraciones ${ }^{101}$. Las actividades sometidas a dicho régimen son las contempladas en el anexo 1 de la Ley 16/2002, de 1 de julio, de Prevención y Control Integrados de la Contaminación, y alguna más relacionada en el anexo 1 de la norma objeto de estudio $^{102}$.

En segundo término, el régimen de licencia ambiental regula un procedimiento que se sustancia, principalmente, en sede local y sobre el que resuelve el alcalde respectivo. Decimos principalmente porque todas las actividades que se considera que se incluyen en el régimen de licencia, menos las relacionadas en el anexo II, se han de someter al trámite de calificación e informe ${ }^{103}$ de unos órganos autonómicos llamados comisiones territoriales de medio ambiente y urbanismo ${ }^{104}$. En relación con la concreción de las actividades que están sometidas a este régimen de licencia, no existe un anexo que las liste de manera completa, pero tenemos una serie de determinaciones que nos ayudarán a conocer las actividades que quedan sometidas a este régimen. Como acabamos de

${ }^{100}$ El Ayuntamiento afectado tiene que emitir como mínimo dos informes: uno sobre la compatibilidad del proyecto con el planeamiento urbanístico y otro sobre la adecuación de la instalación analizada a todos aquellos aspectos que sean de su competencia. Este último informe será valorado por el órgano autonómico que ha de emitir la resolución correspondiente. En relación con el primer informe, cuando sea negativo, siempre que haya entrado en el registro correspondiente de la Junta de Castilla y León antes del otorgamiento de la autorización ambiental, el órgano competente para otorgar la autorización dictará resolución motivada, poniendo fin al procedimiento y ordenando el archivo de las actuaciones. Vid. artículos 13 y 16 de la Ley 11/2003, de 8 de abril, de Prevención Ambiental de Castilla y León, y artículos 15 y 18 de la Ley 16/2002, de 1 de julio, de Prevención y Control Integrados de la Contaminación.

${ }^{101}$ Como, por ejemplo, los organismos de cuenca en el caso de que sea procedente.

${ }^{102}$ Se añaden solo las siguientes actividades:

1. Producción y transformación de metales.

- Instalaciones para el tratamiento de superficie de metales y materiales plásticos por procedimiento electrolítico o químico, cuando el volumen de las cubetas destinadas al tratamiento empleadas sea superior a $30 \mathrm{~m}^{3}$ o su capacidad de producción sea superior a 5.000 toneladas al año.

2. Otras actividades:

- Instalaciones industriales destinadas a la fabricación de:

a) Neumáticos.

b) Vehículos automóviles.

${ }^{103}$ Dicho informe es vinculante cuando supone la denegación de la licencia o la imposición de medidas correctoras adicionales.

${ }^{104}$ De acuerdo con la disposición adicional primera, la Junta de Castilla y León puede delegar, mediante decreto, esta competencia autonómica de calificación e informe de determinadas actividades sometidas al régimen de licencia a los ayuntamientos y a las comarcas legalmente reconocidas, siempre que se cumplan determinados requisitos, como que el ayuntamiento respectivo cuente con un instrumento de planeamiento general y con los servicios técnicos adecuados y que exista una petición previa al respecto. 
revelar, en el anexo II se enumeran aquellas actividades sometidas al régimen de licencia ambiental que están exentas del trámite de calificación e informe del órgano autonómico. Por lo tanto, en todo caso, se someten al citado régimen las actividades relacionadas en el anexo II de la norma objeto de estudio. Asimismo, existe una fórmula general que establece que "quedan sometidas al régimen de licencia ambiental las actividades e instalaciones susceptibles de ocasionar molestias considerables, de acuerdo con lo establecido reglamentariamente y en la normativa sectorial, alterar las condiciones de salubridad, causar daños al medio ambiente o producir riesgos para las personas o bienes". Por otro lado, se establece de manera sistemática y expresa que quedan apartadas de esta intervención "las actividades o instalaciones sujetas al régimen de la autorización ambiental, que se regirán por su régimen propio" ${ }^{\text {105 }}$. De manera que, aparte de la concreción parcial del anexo II y de la fórmula definitoria general de las actividades e instalaciones sometidas a este régimen, tenemos un límite marcado por arriba que corresponde a instalaciones con un potencial de impacto ambiental superior. Además, del análisis de la norma también podemos ver que tenemos un límite por abajo que se refiere a las actividades del anexo $\mathrm{V}$, que se considera que no ocasionan impactos directos considerables sobre el medio en el que se desarrollan y que, por ello, en principio, si el ayuntamiento no decide mediante ordenanza municipal cambiar el régimen de estas actividades estableciendo la necesidad de licencia municipal, se rigen por el régimen de comunicación previa.

De acuerdo con las pretensiones de este estudio, nos interesa destacar que en el régimen de licencia el plazo máximo para resolver y notificar la resolución del procedimiento es de cuatro meses. Si transcurre este plazo sin haberse notificado la resolución, la solicitud podrá entenderse estimada. El período de vigencia de las licencias ambientales es indefinido.

Para acabar, la norma establece un último requisito para iniciar una actividad sometida a autorización ambiental o a licencia ambiental que consiste en que el titular ha de comunicar la puesta en marcha de la actividad a la Administración competente según el caso $^{106}$. Esta comunicación ha de ir acompañada de "la documentación que garantice que la instalación se ajusta al proyecto aprobado, así como a las medidas correctoras

\footnotetext{
${ }^{105}$ Vid. artículo 24 de la Ley 11/2003, de 8 de abril, de Prevención Ambiental de Castilla y León. ${ }^{106}$ Vid. artículo 33 de la Ley 11/2003, de 8 de abril, de Prevención Ambiental de Castilla y León.
} 
adicionales impuestas, en su caso, en la autorización o licencia ambiental"107. Comunicada la puesta en marcha, en el caso de la autorización ambiental no se podrá iniciar la actividad productiva hasta que la Administración competente compruebe, en el plazo de un mes, que las instalaciones realizadas se ajustan al proyecto aprobado y a las medidas correctoras impuestas. Si transcurre el plazo de un mes sin que la Administración haya notificado resolución expresa al respecto, el titular podrá iniciar la actividad. El supuesto de las actividades sujetas a licencia ambiental es diferente, desde el momento en que la presentación de la documentación requerida habilita para el ejercicio de la actividad ${ }^{108}$. Este régimen de comunicación de inicio responde al cambio introducido en la Ley objeto de estudio a través del Decreto-Ley 3/2009, de 23 de diciembre, de Medidas de Impulso de las Actividades de Servicios en Castilla y León, aprobado en aplicación de la Directiva de Servicios y de la Ley 17/2009, de 23 de noviembre, sobre el libre acceso a las actividades de servicios y su ejercicio.

No podemos dar por acabado el estudio de la normativa de esta comunidad autónoma sin antes manifestar que la comunicación de la puesta en marcha de las actividades sometidas a autorización ambiental es más nominal que real desde el momento en que se establece un período de tiempo para que la Administración se manifieste sobre las comprobaciones que ha de realizar y, en el caso de que la Administración no se pronuncie en este período de tiempo, el titular puede iniciar la actividad ${ }^{109}$.

\section{Madrid}

En el ámbito de la Comunidad de Madrid no existe hasta el momento una norma propia que aborde la regulación del procedimiento sustantivo o principal que han de seguir las actividades susceptibles de tener una incidencia ambiental en aras de obtener la autorización o la licencia correspondiente o a emitir la comunicación previa o la declaración responsable, según el caso. Por ello, en este ámbito la Comunidad de Madrid aplica la normativa básica del Estado, representada en la Ley 16/2002, de 1 de

\footnotetext{
${ }^{107}$ Vid. artículo 34 de la Ley 11/2003, de 8 de abril, de Prevención Ambiental de Castilla y León. ${ }^{108}$ Vid. artículo 35.1 y 2 de la Ley 11/2003, de 8 de abril, de Prevención Ambiental de Castilla y León.

${ }^{109}$ Un estudio sobre esta normativa lo encontramos en SANZ RUBIALES, I., "Medio ambiente y Directiva de servicios en Castilla y León", en Vicente Blanco, D. y Rivero Ortega, R. (dirs.), Impacto de la transposición de la Directiva de servicios en Castilla y León, Consejo Económico y Social de Castilla y León, Valladolid, 2010, pp. 614-618. Edición electrónica recuperada el 4 de junio de 2012 de $<$ http://www.cescyl.es/pdf/coleccionestudios/ce13servi.pdf $>$.
} 
julio, de Prevención y Control Integrados de la Contaminación, y en el Real Decreto 509/2007, de 20 de abril, por el que se aprueba el Reglamento para el desarrollo y ejecución de la Ley 16/2002, de 1 de julio, de Prevención y Control Integrados de la Contaminación ${ }^{110}$, y aplica también, en relación con el resto de actividades no incluidas en el anejo 1 de la Ley 16/2002, de 1 de julio, de Prevención y Control Integrados de la Contaminación, el Decreto 2414/1961, de 30 de noviembre, por el que se aprueba el Reglamento de Actividades Molestas, Insalubres, Nocivas y Peligrosas, que mantiene su vigencia en aquellas comunidades autónomas que no tengan normativa aprobada en la materia mientras no se dicte dicha normativa ${ }^{111}$. Es cierto que la Asamblea de Madrid aprobó la Ley 2/2002, de 19 de junio, de Evaluación Ambiental de Madrid, y que en su articulado se dispone que el objeto y la finalidad de la Ley es "establecer el régimen jurídico de los procedimientos ambientales aplicables a los planes, programas, proyectos y actividades, tanto públicos como privados, que se pretenden llevar a cabo en el ámbito territorial de la Comunidad de Madrid, con el fin de garantizar una adecuada protección del medio ambiente ${ }^{\# 12}$, y que una interpretación extensiva de este objeto podía dar pie a que se regularan también los procedimientos principales o sustantivos que se han de seguir para obtener los permisos ambientales correspondientes. Pero la realidad es que en la citada norma solo se ordenan los procedimientos especiales de evaluación de impacto ambiental.

A efectos de nuestro trabajo, ya hemos analizado con anterioridad las excepciones que determina la Ley de Prevención y Control Integrados de la Contaminación en relación con las reglas generales aplicables a las actividades de servicios. Por otro lado, el Reglamento de Actividades Molestas, Insalubres, Nocivas y Peligrosas establece un régimen de licencia individual para cada establecimiento donde el sentido del silencio de la Administración es positivo, salvo que el informe emitido por el órgano competente haya sido desfavorable, y donde, si no se dan circunstancias sobrevenidas, se determina una validez indefinida de la licencia. Una vez obtenida la licencia de instalación, la actividad no podrá comenzar a ejercerse hasta que se realice la visita de comprobación

\footnotetext{
${ }^{110}$ La disposición adicional tercera de la Ley 2/2002, de 19 de junio, de Evaluación Ambiental de Madrid, establece que la Comunidad de Madrid desarrollará la normativa estatal para adecuar los procedimientos de autorización ambiental a su realidad. Mandato del legislador que, por ahora, no ha sido llevado a cabo.

${ }^{111}$ Vid. disposición derogatoria única de la Ley 34/2007, de 15 de noviembre, de Calidad del Aire y Protección de la Atmósfera.

${ }^{112}$ Vid. artículo 1 de la Ley 2/2002, de 19 de junio, de Evaluación Ambiental de Madrid. La cursiva es nuestra.
} 
por el funcionario técnico. Nosotros consideramos que, en todo caso, la normativa de Madrid se tendría que reformar en el sentido de sustituir la visita de comprobación por el funcionario técnico competente por un régimen de comunicación o declaración responsable donde se tengan que presentar certificaciones y documentos que acrediten que la instalación cumple los condicionados y las medidas correctoras de la licencia de instalación de la actividad.

\section{Valencia}

La regulación de los instrumentos de intervención ambiental a los que se han de someter las instalaciones o actividades que son susceptibles de afectar a la seguridad, a la salud de las personas o al medio ambiente en la Comunidad Valenciana se encuentra básicamente en la Ley 2/2006, de 5 de mayo, de Prevención de la Contaminación y Calidad Ambiental, que prevé tres procedimientos de intervención administrativa ambiental aplicables en función de la incidencia ambiental de la actividad que se quiera instalar.

El régimen de autorización ambiental integrada se reserva para las actividades de mayor incidencia ambiental que se encuentran listadas en dos anexos. El anexo I coincide con el anexo I de la Ley básica estatal 16/2002, de 1 de julio, de Prevención y Control Integrados de la Contaminación, y el anexo II incluye actividades susceptibles de generar impactos considerables sobre las que se quiere que se refundan todas las autorizaciones necesarias para que exista una visión global e integrada de todas las incidencias ambientales procedentes de ellas, requerimiento que facilita el procedimiento de la autorización ambiental integrada. La tramitación y resolución de este procedimiento corresponde a la Generalitat después de haberse evacuado todos los informes y trámites correspondientes. Destacamos, entre otros, el informe del ayuntamiento relativo a aquellos aspectos ambientales que sean de competencia municipal, que es preceptivo y vinculante, cuando sea desfavorable o establezca condicionamientos necesarios, para dar visibilidad al acierto de conciliar a través de este instrumento el carácter integrador del procedimiento objeto de estudio junto con el respeto a las competencias municipales. El plazo máximo de resolución y notificación, a 
contar desde la fecha en que la solicitud haya entrado en el registro del órgano competente para resolver, es de diez meses para las actividades del anexo I y de ocho meses para las actividades del anexo II. Si transcurre el plazo señalado sin que se haya notificado la resolución, la solicitud se entenderá desestimada. La vigencia de dicha autorización es de máximo ocho años y su renovación no se puede otorgar por un período superior a los ocho años.

El régimen de licencia ambiental es aplicable a la construcción, montaje, explotación, traslado o modificación sustancial de instalaciones no sometidas a autorización ambiental integrada y que figuran en la relación de actividades del anexo I del Decreto 54/1990, de 26 de marzo, de Actividades Molestas, Insalubres, Nocivas y Peligrosas, que establece el nomenclátor de actividades en la Comunidad Valenciana ${ }^{113}$. La tramitación y la resolución de este procedimiento queda residenciado en el ámbito municipal, y solo en el caso de que el ayuntamiento en cuyo término municipal se ha de instalar la actividad no tenga los medios personales y técnicos para evacuar el informe ambiental, asumirá tal cometido la Comisión Territorial de Análisis Ambiental Integrado de la Generalitat, previo informe del ayuntamiento correspondiente en relación con las materias de competencia municipal ${ }^{114}$. Según la norma objeto de estudio, “el plazo máximo para resolver y notificar la licencia ambiental será de seis meses, a contar desde la fecha en que la solicitud haya tenido entrada en el registro del Ayuntamiento competente para resolver. Transcurrido dicho plazo sin que se haya notificado resolución expresa, podrá entenderse estimada la solicitud presentada, salvo que la licencia suponga conceder al solicitante o a terceros facultades relativas al dominio público o al servicio público, tales como la utilización de la vía pública, en cuyo caso se entenderá desestimada" ${ }^{115}$, y se otorga por período indefinido, sin perjuicio de la obligatoriedad de renovar las diferentes autorizaciones sectoriales necesarias para el ejercicio de la actividad.

113 El nomenclátor de actividades del Decreto 54/1990 se aplicará mientras no se apruebe reglamentariamente, de acuerdo con lo establecido en el artículo 43 de la Ley, la relación de actividades sujetas a licencia ambiental. Vid. artículo 43, disposición transitoria quinta y disposición final cuarta de la Ley 2/2006, de 5 de mayo, de Prevención de la Contaminación y Calidad Ambiental.

114 Al respecto, consúltese el artículo 53 de la Ley 2/2006, de 5 de mayo, de Prevención de la Contaminación y Calidad Ambiental. No hemos de perder de vista que el ayuntamiento ha de solicitar los informes preceptivos a los órganos que deban pronunciarse en función de la actividad objeto de licencia. Vid. artículo 52 de la citada norma.

115 Vid. artículo 55.1 de la Ley 2/2006, de 5 de mayo, de Prevención de la Contaminación y Calidad Ambiental. 
El tercer procedimiento de intervención administrativa ambiental es el de la comunicación ambiental previa al inicio de la actividad, realizada al ayuntamiento respectivo, que se aplica a las actividades inocuas no sujetas a licencia ambiental ni a autorización ambiental integrada. La comunicación ha de ir acompañada de la documentación que se señale en la normativa aplicable ${ }^{116}$ y el ayuntamiento está facultado para comprobar en cualquier momento la veracidad de todos los documentos y datos aportados. Cumpliendo con este régimen, el titular de la actividad o instalación queda totalmente habilitado para abrir y poner en marcha la actividad o la instalación.

A diferencia de este último régimen, en los dos anteriores de autorización y licencia se requiere, antes de iniciar la actividad, una comunicación previa a la Administración competente que haya otorgado la autorización o licencia, acompañada de una serie de documentos que han de garantizar que la instalación se ajusta al proyecto aprobado y que cumple las condiciones y medidas fijadas en el permiso administrativo correspondiente. La norma objeto de estudio establece en un artículo rubricado "régimen de silencio administrativo" que, pasado un mes para las actividades que hayan obtenido licencia ambiental y dos meses para las actividades que tengan una autorización ambiental sin que existan reparos $\mathrm{u}$ oposición por parte de la Administración, se entenderá otorgada licencia de apertura, pudiéndose iniciar la actividad. Nos parece muy llamativo, por contradictorio, que, por una parte, se establezca como requisito de apertura la comunicación previa y, por otra, se diga que una vez seguido este régimen de comunicación se entiende otorgada la licencia de apertura. Nosotros entendemos que, o existe un régimen de comunicación previa a la apertura de la actividad, o existe un régimen de licencia de apertura de la actividad. Posiblemente, esta contradicción se debe a que la reforma operada recientemente a través del Decreto-Ley 2/2012, de 13 de enero, ha querido adaptar la norma objeto de estudio a las nuevas exigencias derivadas de la Directiva de Servicios y de la normativa estatal que la transpone, sustituyendo la autorización de inicio de la actividad o la licencia de apertura, según el caso, por la comunicación previa a la apertura de la instalación o actividad sin tener claro que la comunicación previa no se configura como una solicitud que requiera una resolución de la Administración, y en relación con la

\footnotetext{
${ }^{116}$ El artículo 65.2 nos ilustra sobre la documentación que ha de acompañar a la comunicación, pero también se señala que "reglamentariamente se podrá determinar aquella otra documentación que deba acompañar a la comunicación ambiental, sin perjuicio de las previsiones que puedan ser incorporadas por los Ayuntamientos en sus correspondientes ordenanzas municipales".
} 
cual, si no hay resolución expresa, se ha de establecer un régimen de silencio administrativo, sino que esta institución se configura, tal como se determina en la letra n) del artículo 4 de la Ley objeto de análisis ${ }^{117}$ y en el artículo 71 bis de la Ley 30/1992, como un mecanismo mediante el cual el interesado o titular pone en conocimiento de la Administración, a través de un documento, una serie de datos identificativos y de requisitos que le habilitan para ejercer un derecho o para iniciar una actividad, sin que quepa dentro de esta figura un régimen de silencio administrativo para entender otorgado un permiso para que pueda operar la actividad. En definitiva, nos encontramos otra vez ante una comunicación previa más nominal que sustantiva.

\section{La Rioja}

En la Comunidad de la Rioja disponemos de una norma que abarca de manera omnicomprensiva los diferentes instrumentos y mecanismos de protección medioambiental $^{118}$. Nos referimos a la Ley 5/2002, de 8 de octubre, de Protección del Medio Ambiente de La Rioja. Entre otros mecanismos, esta norma aborda, de una manera muy esquemática, la regulación de los instrumentos de control que sirven para habilitar, desde el punto de vista medioambiental, de la seguridad y de la salud, el funcionamiento de las instalaciones y actividades susceptibles de producir efectos en el medio ambiente, la seguridad y la salud de las personas. En este ámbito se prevé un régimen de autorización ambiental integrada y otro de licencia ambiental que son excluyentes, de manera que si el titular de una actividad la somete a autorización ambiental integrada, no tendrá que someter la actividad al régimen de obtención de la licencia ambiental. El desarrollo normativo de estos instrumentos de intervención administrativa lo encontramos en el Decreto 62/2006, de 10 de noviembre, por el que se aprueba el Reglamento de Desarrollo del Título I, Intervención Administrativa, de la Ley 5/2002, de 8 de octubre, de Protección del Medio Ambiente de La Rioja.

\footnotetext{
${ }^{117}$ Letra introducida en el artículo 4 de la Ley por la disposición final 3.1 del Decreto-Ley 2/2012, de 13 de enero.

${ }^{118}$ Decimos de manera omnicomprensiva porque en esta norma se regulan, aunque sea mínimamente, el instrumento de la evaluación de impacto ambiental, los planes y programas de protección ambiental, los sistemas de gestión y auditorías medioambientales, los distintivos de garantía de calidad ambiental, la difusión de la información ambiental, la participación pública, los instrumentos económicos y de gestión, y también, entre otras cuestiones, la autorización ambiental integrada de proyectos y actividades y la licencia ambiental.
} 
Se someten al régimen de autorización ambiental las actividades del anexo I de la Ley 16/2002, de 1 de julio, de Prevención y Control Integrados de la Contaminación, que se quieran implantar $^{119}$ en la Comunidad Autónoma de la Rioja ${ }^{120}$. La tramitación y resolución de este instrumento se residencian en el ámbito autonómico, aunque será necesaria la intervención del municipio donde haya de ubicarse la instalación para que evacue los informes relativos a las competencias municipales afectadas.

Se someten a licencia ambiental las actividades e instalaciones no incluidas en el ámbito de la autorización ambiental y que sean susceptibles de causar molestias o producir riesgos a las personas y bienes o de originar daños al medio ambiente. No obstante esta definición genérica, el Reglamento establece, por una parte, en el anexo $\mathrm{V}$ las actividades que a título enunciativo están sujetas al régimen de licencia ambiental ${ }^{121} \mathrm{y}$, por otra, la posibilidad de que a través de una orden de la Consejería competente en materia de medio ambiente se determine que por debajo de determinados parámetros ciertas actividades e instalaciones puedan resultar exentas de la obligación de obtener licencia ambiental por su escasa incidencia en el medio ambiente o en la salud de las personas $^{122}$. Hasta el momento no se ha utilizado esta posibilidad ${ }^{123}$, que permitiría echar mano de otros mecanismos que en teoría han de ser menos onerosos para los titulares de las instalaciones o actividades y, por lo tanto, más acordes con los postulados de la Directiva de Servicios y sus normas de transposición. En el régimen de licencia ambiental, la solicitud se presenta en el ayuntamiento afectado por la actividad que se quiere llevar a cabo y en su tramitación se ha de solicitar a los órganos competentes informe sobre prevención de incendios, protección de la salud y generación de residuos y vertidos, atmósfera y suelo. La resolución que pone fin al procedimiento es competencia del alcalde, que la ha de dictar en el plazo máximo de cuatro meses a

\footnotetext{
${ }^{119}$ En el caso de que la actividad solicite una modificación sustancial de la instalación, también se ha de someter a este régimen.

${ }^{120}$ Las actividades relacionadas en el anexo IV, titulado "Actividades sometidas a autorización ambiental integrada", del Decreto 62/2006, de 10 de noviembre, por el que se aprueba el Reglamento de Desarrollo del Título I, Intervención Administrativa, de la Ley 5/2002, de 8 de octubre, de Protección del Medio Ambiente de La Rioja, son las mismas que las relacionadas en el anexo I de la Ley estatal.

${ }^{121}$ En concreto, en el anexo V se dice que están sujetas a licencia ambiental las actividades de los anexos I, II y IV del Reglamento que no lleguen a los umbrales previstos en los ellos y, además, las actividades que se pasan a enumerar.

${ }^{122}$ El Reglamento, en la disposición transitoria segunda, establece que, mientras no se dicte la Orden a la que se hace referencia, se han de someter a licencia las actividades e instalaciones incluidas en el ámbito de aplicación explicado.

${ }^{123}$ En fecha 31 de mayo de 2012 no se había utilizado este recurso.
} 
contar desde la fecha de presentación de la solicitud. Si transcurre este plazo sin que haya recaído resolución expresa, se entenderá que la solicitud de licencia ha sido denegada $^{124}$.

Se prevé que las actividades, tanto las sometidas al régimen de autorización como las sometidas al régimen de licencia, se sujeten también a licencias o autorizaciones de apertura $^{125}$. Nosotros consideramos que estas exigencias en sede de apertura o puesta en marcha de la actividad no son proporcionadas y no están justificadas en aras de proteger el medio ambiente y el entorno urbano y que, en este ámbito, sería suficiente utilizar el régimen de comunicación previa o de declaración responsable, en el que se tuvieran que presentar, entre otros documentos, certificados de entidades acreditadas según los cuales la instalación cumple todos los requisitos y condicionantes establecidos en el permiso administrativo de instalación.

\section{Cataluña}

La Ley 20/2009, de 4 de diciembre, de Prevención y Control Ambiental de Actividades de Cataluña, establece, entre otras cuestiones, el sistema de habilitación administrativo ambiental relativo al establecimiento de las actividades con incidencia ambiental, integrando en este sistema la evaluación de impacto ambiental de las actividades. Este sistema está formado por el régimen de autorización ambiental, el régimen de licencia ambiental y el régimen de comunicación, pivotando todos ellos sobre el eje de la prevención y la reducción de la contaminación en el medio.

Dentro del régimen de autorización, hemos de distinguir entre las actividades sometidas a autorización ambiental con declaración de impacto ambiental, que son las del anexo I. $1^{126}$ y el anexo I.2.a $)^{127}$, y las actividades sometidas a autorización ambiental y a un proceso de decisión previa sobre la necesidad de sometimiento a una evaluación de

\footnotetext{
${ }^{124}$ El alcalde puede prorrogar el plazo, a través de una resolución motivada, siempre que lo considere necesario por la dificultad del asunto. Vid. artículo 59.1 del Decreto.

${ }^{125}$ Vid. artículo 48.2 y artículo 59.4 del Decreto.

126 Actividades sometidas al régimen de evaluación de impacto ambiental y sujetas a la Directiva 2008/1/CE del Parlamento Europeo y del Consejo, de 15 de enero de 2008, relativa a la prevención y al control integrados de la contaminación.

127 Actividades sometidas a autorización ambiental con declaración de impacto ambiental que están incluidas en el anexo I del texto refundido de la Ley de Evaluación de Impacto Ambiental de Proyectos, aprobado por el Real Decreto Legislativo 1/2008, de 11 de enero, no sujetas a la Directiva 2008/1/CE, así como todas las actividades y las instalaciones afectadas por la legislación de accidentes graves.
} 
impacto ambiental, que son las actividades relacionadas en el anexo I.2.b) ${ }^{128}$. La Administración de la Generalitat es la competente para resolver el procedimiento único en que se integran estos sistemas de intervención, sin perjuicio de la intervención de otras administraciones a través de los referidos informes preceptivos y vinculantes, entre los que destacamos el informe municipal relativo a sus competencias ambientales $^{129}$. La resolución, que dicta el órgano ambiental del departamento competente en materia de medio ambiente, se ha de dictar y notificar en el plazo de ocho meses, si no, se entenderá que la solicitud ha sido desestimada ${ }^{130}$. La validez de la autorización es para un período de ocho años en el caso de las actividades del anexo I.1, y para un período de doce años en el caso de las actividades del anexo I. $2^{131}$.

Se someten al régimen de licencia las actividades del anexo $\mathrm{II}^{132}$. El procedimiento de licencia es de competencia municipal, con la intervención de las administraciones afectadas a través de los informes preceptivos y vinculantes como, por ejemplo, y dependiendo de la actividad y sus afectaciones al medio, el informe de la Administración hidráulica de Cataluña, el informe de la Administración de residuos de Cataluña, el informe del órgano ambiental del departamento competente en materia de protección del ambiente atmosférico o el informe de la Administración forestal. La

\footnotetext{
${ }^{128}$ Incluye actividades que se ha considerado necesario someter a autorización ambiental y que se incluyen en el anexo II del texto refundido de la Ley de Evaluación de Impacto Ambiental de Proyectos, aprobado por el Real Decreto Legislativo 1/2008, de 11 de enero, y que, por lo tanto, han de pasar un proceso de decisión previa sobre la necesidad de sometimiento a evaluación de impacto ambiental.

129 Como expresa el artículo 8.2 de la norma objeto de estudio: "Los Ayuntamientos tienen una intervención preceptiva en cuanto a contaminación por ruidos, vibraciones, calor, olores, suministro de aguas, vertidos al sistema público de saneamiento o al alcantarillado municipal y gestión de residuos municipales". Señalamos, además, que la solicitud de la autorización ambiental ha de ir acompañada de un informe urbanístico del ayuntamiento donde se quiere ubicar la actividad que acredite la compatibilidad de la actividad con el planeamiento urbanístico y la disponibilidad y suficiencia de los servicios públicos que requiera la actividad.

${ }^{130}$ Vid. artículo 28 de la Ley 20/2009, de 4 de diciembre, de Prevención y Control Ambiental de Actividades de Cataluña.

131 Vid. artículo 62.1 de la Ley 20/2009, de 4 de diciembre, de Prevención y Control Ambiental de Actividades de Cataluña.

${ }^{132}$ Dentro de estas, en todo caso, las actividades de los apartados 11.1 y 11.2 integran en el procedimiento la evaluación de impacto ambiental y las actividades del epígrafe 7.9 deben someterse, previamente a la solicitud de la licencia, a la decisión del órgano ambiental competente del Departamento de Medio Ambiente y Vivienda respecto de la necesidad de someterse o no a la evaluación de impacto ambiental. Por otro lado, las actividades del anexo II y las del anexo IV que no se sometan al régimen de licencia establecido por la normativa administrativa de los espectáculos públicos y las actividades recreativas deben formular una consulta previa a la Administración respecto al hecho de someterlas a una evaluación de impacto ambiental aplicando los criterios del anexo $\mathrm{V}$, siempre que las actividades afecten directamente a determinados espacios naturales, zonas húmedas y otras zonas protegidas. Vid. artículo 33.1 Ley 20/2009, de 4 de diciembre, de Prevención y Control Ambiental de Actividades de Cataluña.
} 
resolución la dicta y notifica el ayuntamiento en el plazo máximo de seis meses desde la fecha de presentación de la solicitud; si no ocurre de esta manera, la solicitud se entenderá desestimada. La licencia ambiental “está sujeta a las revisiones periódicas que determine la legislación sectorial en materia de agua, aire o residuos" ${ }^{\text {"133 }}$.

Antes de su puesta en funcionamiento, tanto las actividades sometidas al régimen de autorización como las actividades sometidas al régimen de licencia se han de someter a un control ambiental inicial, en el plazo establecido por la autorización o la licencia ambientales, que culmina con el acta de control ambiental inicial realizada, como regla general, por una entidad colaboradora de la Administración ${ }^{134}$ que la ha de presentar a la Administración competente y que sirve para verificar el cumplimiento de las condiciones de la autorización o la licencia ambientales y, por lo tanto, para habilitar el ejercicio de la actividad ${ }^{135}$.

Por último, se someten al régimen de comunicación las actividades del anexo III. Este régimen también es de competencia municipal y se ha de formalizar ante el ayuntamiento cuando ya se han acabado las obras y las instalaciones necesarias para llevar a cabo la actividad ${ }^{136}$. La comunicación hace girar la prevención ambiental sobre el instrumento de la certificación técnica del cumplimiento de las normas ambientales $^{137}$, a la vez que, cumplida la formalización de la comunicación, se

\footnotetext{
${ }^{133}$ Vid. artículo 62.2 Ley 20/2009, de 4 de diciembre, de Prevención y Control Ambiental de Actividades de Cataluña.

${ }^{134}$ Para las actividades del anexo II y IV, el ayuntamiento puede encomendar los controles iniciales a los servicios técnicos municipales. En relación con el impacto general de la Directiva de Servicios sobre las entidades colaboradoras de la Administración, vid., entre otros, NOGUEIRA LÓPEZ, A., "Entidades colaboradoras de la Administración, libre prestación de servicios y régimen de control preventivo de actividades", en Revista Aranzadi de Derecho Ambiental, núm. 16, 2009.

${ }^{135}$ Vid. artículos 69 y 70 de la Ley 20/2009, de 4 de diciembre, de Prevención y Control Ambiental de Actividades de Cataluña.

${ }^{136}$ Estas obras e instalaciones han de estar respaldadas por la licencia urbanística correspondiente o la comunicación previa de obras no sujetas a licencia, y también por el resto de las licencias sectoriales que sean necesarias. Vid. artículo 52.1 de la Ley 20/2009, de 4 de diciembre, de Prevención y Control Ambiental de Actividades de Cataluña.

${ }^{137}$ En concreto, la comunicación ha de ir acompañada de la siguiente documentación:

— La descripción de la actividad mediante un proyecto básico con memoria ambiental.

- La certificación entregada por el personal técnico competente que acredite que la actividad y las instalaciones se adecuan al estudio ambiental y al proyecto y que se cumplen todos los requisitos ambientales.

- Cuando se establezca reglamentariamente para comprobar las emisiones de la actividad a la atmósfera o al agua o para caracterizar determinados residuos, la comunicación también se acompañará de una certificación realizada por una entidad colaboradora de la Administración ambiental o por los servicios técnicos municipales.
} 
responsabiliza a los titulares de la actividad y al personal técnico de su apertura y ejercicio $^{138}$. Antes de acabar, no podemos olvidar que, a pesar de que este es un régimen que se residencia en sede municipal, si estamos ante una actividad que vierte aguas residuales al lecho público o al mar, se ha de someter al régimen de autorización de vertidos, y si la actividad se sitúa en un espacio natural protegido, se ha de someter al proceso de consulta previa respecto a la necesidad de evaluación de impacto ambiental.

Destacamos, además, que el legislador catalán deja la puerta abierta a que, a través de las ordenanzas municipales, algunas de las actividades del anexo II pasen a someterse al régimen de comunicación en función de la ubicación urbanística, de las características ambientales del medio receptor y de otros factores de incidencia ambiental, siempre y cuando no lo impida el cumplimiento de la normativa sectorial ambiental ${ }^{139}$.

En definitiva, la normativa catalana es un ejemplo de aplicación de los postulados generales de la Directiva de Servicios y de realización de una interpretación restrictiva en relación con la posibilidad de excepcionar estas reglas generales. Hay que tener muy presente que, aparte de que el gran número de actividades del anexo III representan aproximadamente el $80 \%-90 \%$ del total, los ayuntamientos pueden incrementar las actividades que se someten al régimen de comunicación previa a través de ordenanzas municipales. Asimismo, no hay que perder de vista que este régimen de comunicación previa se basa en que se han de presentar unos certificados que sirven para garantizar la legalidad de la instalación y la comprobación de sus emisiones y que la responsabilidad del funcionamiento de la actividad queda residenciada en manos privadas, tanto de los propietarios como de los técnicos que certifican y que operan la instalación. Por otro lado, el no establecimiento de controles ex post periódicos de estas instalaciones sometidas a comunicación previa se tendría que compensar con el ejercicio de la posibilidad establecida de los autocontroles y con el ejercicio persuasivo $y$ ejemplificante de la inspección administrativa, que se ha de ejercer de verdad inspeccionando in situ las instalaciones y sancionando en función del resultado de la

\footnotetext{
${ }^{138}$ Vid. artículo 52.5 de la Ley 20/2009, de 4 de diciembre, de Prevención y Control Ambiental de Actividades de Cataluña.

${ }^{139}$ Vid. preámbulo y artículo 7.1.d) Ley 20/2009, de 4 de diciembre, de Prevención y Control Ambiental de Actividades de Cataluña.
} 
inspección. Cuestión esta que está por ver y que se vislumbra difícil de abarcar por el gran número de actividades que representan ${ }^{140}$.

\section{País Vasco}

En el ámbito territorial del País Vasco nos encontramos con la Ley 3/1998, de 27 de febrero, de Protección del Medio Ambiente del País Vasco, que regula, entre otras cuestiones, la intervención administrativa sobre las genéricamente denominadas por la citada norma como actividades clasificadas ${ }^{141}$. Esta norma autonómica y la norma básica estatal sobre prevención y control integrados de la contaminación definen el sistema de autorización de dichas actividades en el País Vasco. La normativa autonómica se redacta de manera flexible y abierta, lo que posibilita la cabida de las bases estatales. Así, todas las actividades del anexo I de la Ley 16/2002, de 1 de julio, de Prevención y Control de la Contaminación, siguen el régimen de autorización autonómico establecido en la norma básica estatal, en el que se contempla la decisiva intervención del municipio en el que se instala la actividad en todos aquellos aspectos que sean de su competencia.

Por otro lado, dentro del listado genérico de actividades e instalaciones clasificadas del anexo II de la Ley vasca quedan englobadas e incluidas algunas que tienen escasa incidencia en el medio ambiente y en la salud de las personas y, por ello, resultan exentas de la obtención de la licencia de actividad que se aplica al resto de actividades que sí son susceptibles de causar molestias, producir riesgos a las personas o sus bienes, así como originar daños al medio ambiente. Ahora bien, que determinadas actividades estén exentas de la licencia de actividad no quiere decir que queden exoneradas de toda

\footnotetext{
${ }^{140}$ En relación con esta necesidad de compensar y equilibrar ambas pretensiones, LUCIA CASADO CASADO afirma: "Con la finalidad de simplificar el procedimiento y reducir cargas en los titulares de actividades y con el objetivo último de promoción de la actividad económica se están flexibilizando en buena medida el grado de protección ambiental, los sistemas de control de las actividades y los estándares ambientales. En este contexto, es imprescindible encontrar los adecuados mecanismos de equilibrio entre una ajustada carga administrativa y las garantías ambientales con el fin de garantizar la preservación del medio ambiente". Vid. su artículo "Novedades en el régimen de prevención y control ambiental de actividades en Cataluña: Retroceso en la protección del medio ambiente versus promoción de la actividad económica", en Revista Catalana de Dret Ambiental, vol. III, núm. 1, 2012, p. 45.

${ }^{141}$ Según el artículo 55.1 de la Ley 3/1998, de 27 de febrero, de Protección del Medio Ambiente del País Vasco, las actividades e instalaciones públicas o privadas que son susceptibles de originar daños al medio ambiente, a las personas o a sus bienes, generar riesgos de producir tales daños o causar molestias a las personas adoptan la denominación genérica de actividades e instalaciones clasificadas.
} 
intervención administrativa sobre ellas, sino que estas actividades quedan sujetas al régimen de comunicación previa de actividad clasificada ${ }^{142}$.

Por lo tanto, las actividades clasificadas no incluidas en el anexo I de la Ley básica estatal y que tampoco están exentas de la obtención de la licencia de actividad son las que se han de someter al régimen de la licencia de actividad. Esta se solicita ante el ayuntamiento en cuyo término municipal se quiere implantar la actividad, sigue su iter procedimental $^{143} \mathrm{y}$, finalmente, la autoridad municipal ha de dictar la resolución en un tiempo no superior a seis meses desde que se presentó formalmente la solicitud de licencia ante el ayuntamiento. Si se supera este plazo sin mediar paralización del procedimiento imputable al solicitante, se entenderá otorgada la licencia, salvo en aquellos casos en que el órgano ambiental de la Comunidad Autónoma u órgano foral competente hubiese notificado un informe desfavorable ${ }^{144}$ y este esté pendiente de ejecución por parte del ayuntamiento. No se establece plazo de validez de la licencia; por lo tanto, se presupone una validez indefinida, que quedaría sin efecto si se incumplieran las condiciones de la licencia y sería revocada si se conocieran circunstancias que hubieran justificado la denegación de la licencia ${ }^{145}$. Por último, se establece que para obtener la licencia de obras es necesario tener concedida previamente la licencia de actividad clasificada ${ }^{146} \mathrm{y}$, además, se exige que, una vez implantadas las medidas correctoras impuestas en la licencia de actividad y habilitadas las instalaciones, el inicio de la actividad quede sujeto al régimen de comunicación previa ${ }^{147}$.

\footnotetext{
${ }^{142}$ La clasificación de las actividades sujetas a uno u otro régimen se ha realizado teniendo en cuenta aspectos como los siguientes: la dimensión y capacidad de producción de la instalación; el consumo de agua, energía y otros recursos; la cantidad, el peso y la tipología de los residuos generados; las emisiones potenciales a la atmósfera y a las aguas; el riesgo de accidente; y el uso de sustancias peligrosas.

${ }^{143}$ Con la información pública y la solicitud de informes ambientales y sectoriales que han de evacuar, según el caso, los órganos competentes de la Comunidad Autónoma o los órganos forales y los órganos ambientales de los ayuntamientos con capacidad técnica suficiente. En relación con el procedimiento en general, vid. artículos 57, 58, 59, 60 y 62 de la Ley 3/1998, de 27 de febrero, de Protección del Medio Ambiente del País Vasco.

${ }^{144}$ Este informe, que emite el órgano ambiental de la Comunidad Autónoma u órgano foral competente, es vinculante para la autoridad municipal cuando es contrario a la concesión de la licencia, así como cuando señala la necesidad de establecer medidas correctoras. Vid. artículo 59.2 de la Ley 3/1998, de 27 de febrero, de Protección del Medio Ambiente del País Vasco.

${ }^{145}$ Vid. artículo 59 bis de la Ley 3/1998, de 27 de febrero, de Protección del Medio Ambiente del País Vasco.

146 Vid. artículo 61.1 de la Ley 3/1998, de 27 de febrero, de Protección del Medio Ambiente del País Vasco.

147 Según los apartados 3 y 4 del artículo 61 Ley 3/1998, de 27 de febrero, de Protección del Medio Ambiente del País Vasco.
} 
No podemos dar por acabado el comentario sobre esta comunidad autónoma sin antes mencionar que el panorama legislativo plasmado refleja las modificaciones introducidas en la Ley 3/1998, de 27 de febrero, de Protección del Medio Ambiente del País Vasco, por la reciente Ley 7/2012, de 23 de abril, que modifica diversas leyes vascas para su adaptación a la Directiva de Servicios. Con anterioridad a esta reforma nos encontrábamos, por una parte, con muchas actividades sin apenas afectación e incidencia sobre el medio ambiente o posibilidad de generar riesgos o causar molestias a las personas sometidas a licencia de actividad clasificada, y, por otra, se exigía a las actividades sometidas a licencia de actividades clasificadas que antes del inicio de la actividad obtuvieran la licencia de apertura. La falta de proporcionalidad de estas disposiciones de acuerdo con los postulados de la Directiva de Servicios justifica la citada reforma.

\section{Islas Baleares}

En la Comunidad Autónoma de las Islas Baleares, para conocer la articulación de las autorizaciones administrativas relativas al establecimiento y la instalación de las tradicionalmente denominadas actividades clasificadas hemos de referirnos a la Ley 16/2006, de 17 de octubre, de Régimen Jurídico de las Licencias Integradas de Actividad de las Illes Balears. Esta norma regula las actividades clasificadas y las actividades afectadas por la normativa de los espectáculos públicos y las actividades recreativas, de manera que las actividades permanentes afectadas por ambas normativas integran, en los procedimientos para obtener los permisos de instalación correspondientes, los requerimientos y las exigencias propios de la normativa de los espectáculos públicos y las actividades recreativas.

Por otro lado, la Ley balear afirma que las actividades sujetas al régimen de la autorización ambiental integrada de la Ley 16/2002, de 1 de julio, de Prevención y Control Integrados de la Contaminación, y a la normativa autonómica que la desarrolle siguen el procedimiento de intervención administrativa establecido en esta normativa sectorial $^{148}$. Para el resto de actividades clasificadas ha influido, de manera decisiva, la normativa acabada de citar en su pretensión de integrar en el procedimiento todos los impactos de los diferentes sectores ambientales, $\mathrm{y}$, por ello, en sus procedimientos nos

\footnotetext{
${ }^{148}$ Vid. artículo 25 de la Ley 16/2006, de 17 de octubre, de Régimen Jurídico de las Licencias Integradas de Actividad de las Illes Balears.
} 
encontramos con "dictámenes integrados" y en el título de la norma se hace referencia a "las licencias integradas".

Con carácter general, podemos decir que las actividades clasificadas no incluidas en el anexo I de la Ley básica estatal se denominan, en la Ley objeto de estudio, actividades permanentes, que se dividen en mayores, menores e inocuas. Las actividades permanentes mayores ${ }^{149}$ han de seguir un procedimiento para obtener el correspondiente permiso de instalación ${ }^{150}$ que se desarrolla en sede municipal. El eje de este procedimiento es el "dictamen integrado previo", en el que se dictamina sobre la licencia municipal y sobre las medidas preventivas, correctoras y de control posterior ${ }^{151}$. Este permiso de instalación se ha de resolver y notificar en el plazo máximo de tres meses a partir de la presentación completa de la documentación exigida. Cuando estemos ante ayuntamientos que no son competentes para emitir el "dictamen integrado" de la actividad, el permiso será resuelto y notificado en el plazo máximo de cuatro meses a contar desde la presentación de la documentación exigida. El silencio administrativo tiene efectos estimatorios.

Antes de la última reforma experimentada por la norma objeto de estudio, las actividades permanentes menores ${ }^{152}$ seguían, para obtener el correspondiente permiso de instalación, una tramitación exclusivamente municipal. Este permiso tenía que ser resuelto y notificado en el plazo máximo de un mes a partir de la presentación de toda la documentación exigida. La falta de resolución expresa tenía también efectos estimatorios. Ambos tipos de actividades, las permanentes mayores y menores, una vez obtenido el permiso de instalación y ejecutadas las instalaciones, las obras y las medidas correctoras, y antes de iniciar la actividad, tenían que presentar ante el ayuntamiento la solicitud de la licencia de apertura y funcionamiento ${ }^{153}$ adjuntando la documentación

\footnotetext{
${ }^{149}$ Son aquellas que necesitan un mayor grado de seguridad y control administrativo, especificadas en el artículo 6 de la Ley.

150 Según el artículo 4.22: "Es el título administrativo que permite, si procede, la ejecución de las instalaciones".

151 Este dictamen será municipal o no en función del número de habitantes del municipio y de su capacidad.

${ }^{152}$ Antes de la reforma se definían como aquellas que necesitan un grado inferior de seguridad y control administrativo, especificadas en el título II, anexo I, de la Ley. Después de la reforma se definen como todas las actividades que no sean mayores ni inocuas.

153 Según el artículo 4.18: "Es el título administrativo que recoge el condicionamiento de todas las autorizaciones sectoriales de aplicación, de las medidas preventivas, correctoras y de control impuestas y que permitirá, sólo entonces, el inicio de la actividad".
} 
que establecía la normativa. Esta licencia se tenía que resolver y notificar en el plazo máximo de 15 días a partir de la presentación completa de la documentación exigida. Si en este plazo no se había dictado y notificado una resolución expresa, la solicitud se entendía estimada.

Finalmente, las actividades permanentes inocuas estaban sujetas únicamente a comunicación previa al ayuntamiento mediante un escrito acompañado de la documentación requerida. El ayuntamiento disponía de un mes como máximo para constatar que la documentación aportada era completa y se ajustaba a lo establecido legalmente. Transcurrido este plazo sin que se hubiera notificado resolución en contra, se podía iniciar la actividad. Una vez más teníamos que denunciar que no estábamos ante un régimen de comunicación previa sustantivo que permitiera el inicio de una actividad desde el día de su presentación ${ }^{154}$.

Pocos días antes de cerrar este trabajo se modifica la Ley balear a través del DecretoLey 7/2012, de 15 de junio, de medidas urgentes para la activación económica en materia de industria y energía, y otras actividades, de manera que la estructura descrita se modifica en el sentido de que solo necesitan permiso de instalación las actividades permanentes mayores. El resto de actividades, tanto las permanentes menores como las inocuas $^{155}$, para iniciar y ejercer su actividad únicamente deben presentar la declaración responsable correspondiente junto con el resto de documentación. Además, también se suprime la licencia de apertura y funcionamiento que se exigía a las actividades permanentes mayores y menores.

\section{Andalucía}

La Comunidad Autónoma de Andalucía regula la intervención ambiental de las instalaciones potencialmente lesivas para el medio ambiente a través de la Ley 7/2007,

\footnotetext{
${ }^{154}$ Vid. artículo 71 bis de la Ley 30/92, de 26 de noviembre, de Régimen Jurídico de las Administraciones Públicas y del Procedimiento Administrativo Común.

${ }^{155}$ Según el nuevo redactado del artículo 8, son actividades permanentes inocuas:

a) Los aparcamientos al aire libre.

b) Las actividades de uso administrativo, comercial y de aparcamiento de hasta $300 \mathrm{~m}^{2}$ de superficie, y, en todo caso, las actividades incluidas dentro del ámbito de aplicación del Real Decreto-Ley 19/2012, de 25 de mayo, de Medidas Urgentes de Liberalización del Comercio y de Determinados Servicios.

c) El resto de actividades, no mayores y no indicadas en los apartados anteriores, de hasta $100 \mathrm{~m}^{2} \mathrm{de}$ superficie.
} 
de 9 de julio, de Gestión Integrada de la Calidad Ambiental. Los instrumentos que contempla esta norma para prevenir y controlar la incidencia ambiental de estas instalaciones son la autorización ambiental integrada, la autorización ambiental unificada y la calificación ambiental. Todos ellos incorporan e integran en sus respectivos procedimientos la evaluación de impacto ambiental de la actividad correspondiente $^{156}$. Una vez resueltos estos procedimientos, estas actividades podrán obtener la licencia municipal de actividad correspondiente ${ }^{157}$.

De acuerdo con la Ley andaluza, se someten a autorización ambiental integrada la construcción, montaje, explotación, traslado y modificación sustancial de aquellas actuaciones indicadas en el anexo I de la citada Ley, actuaciones que coinciden con las relacionadas en el anexo I de la Ley 16/2002, de 1 de julio, de Prevención y Control Integrados de la Contaminación. La tramitación y resolución de este procedimiento corresponde a la Consejería competente en materia de medio ambiente. Además, la autorización ambiental integrada podrá incorporar la exigencia de comprobación de aquellos condicionantes que se estimen oportunos con anterioridad a la puesta en marcha de la actividad ${ }^{158}$.

Por otro lado, se someten a autorización ambiental unificada ${ }^{159}$ la instalación y la modificación sustancial de las actuaciones, tanto públicas como privadas, así señaladas en el anexo I de la Ley andaluza; las actividades sometidas a calificación ambiental que se extiendan a más de un municipio; las actuaciones públicas y privadas que, no estando incluidas entre las acabadas de citar, puedan afectar directa o indirectamente a los espacios de la red ecológica europea Natura 2000 cuando así lo decida la Consejería

\footnotetext{
${ }^{156}$ Según el artículo 16 de la norma: "En los casos en que la evaluación de impacto ambiental sea competencia de la Administración General del Estado, la declaración de impacto ambiental resultante [...] se incorporará en la autorización ambiental integrada o autorización ambiental unificada que en su caso se otorgue".

${ }^{157}$ Vid. artículo 17.2 de la Ley andaluza.

${ }^{158}$ La puesta en marcha se llevará a cabo una vez que se traslade a la Consejería competente en materia de medio ambiente la certificación del técnico director de la instalación que acredita que esta se ha realizado de acuerdo con el proyecto presentado y el condicionado de la autorización, y la podrá realizar la Consejería competente en materia de medio ambiente o entidades colaboradoras en materia de protección ambiental. Vid. artículos 25.2, 26.1 y 2 de la Ley andaluza.

${ }^{159}$ El artículo 28 establece lo siguiente: "La autorización ambiental unificada tiene por objeto evitar o, cuando esto no sea posible, reducir en origen las emisiones a la atmósfera, al agua y al suelo y otras incidencias ambientales de determinadas actuaciones, así como recoger en una única resolución las autorizaciones y pronunciamientos ambientales que correspondan a la Consejería competente en materia de medio ambiente y entidades de derecho público dependientes de la misma, y que resulten necesarios con carácter previo para la implantación y puesta en marcha de estas actuaciones".
} 
competente en materia de medio ambiente; las actuaciones sometidas a autorización ambiental integrada y las sometidas a autorización ambiental unificada de acuerdo con el anexo I, y las modificaciones de estas cuando sirvan exclusiva o principalmente para desarrollar o ensayar nuevos métodos o productos y que no se utilicen por más de dos años cuando así lo decida la Consejería competente en materia de medio ambiente; y, por último, otras actuaciones que deban ser sometidas a evaluación de impacto ambiental por exigencia de la legislación básica estatal. Corresponde a la Consejería competente en materia de medio ambiente la tramitación y resolución del procedimiento para obtener esta autorización. Dicha Consejería tiene un plazo de ocho meses desde la presentación de la solicitud para resolver y notificar la resolución con la que finaliza el procedimiento. Si transcurre dicho plazo sin haberse notificado la resolución, la solicitud se entenderá desestimada. La norma prevé un procedimiento abreviado para aquellas instalaciones señaladas con un asterisco en el anexo I. En estos casos el plazo de resolución y notificación será de seis meses, y si transcurre el plazo sin que se haya notificado resolución expresa, también podrá entenderse desestimada la solicitud. En esta autorización, al igual que en la autorización ambiental integrada, se podrá incorporar la exigencia de comprobación de aquellos condicionantes que se estimen oportunos con anterioridad a la puesta en marcha de la actividad. La comprobación se realizará de la misma manera prevista para la autorización ambiental integrada ${ }^{160}$.

Para acabar, la calificación ambiental ${ }^{161}$ se desarrolla en sede municipal y su procedimiento se integra en el de la correspondiente licencia municipal de actividad $^{162}$.

\section{Galicia}

La intervención administrativa sobre las actividades tradicionalmente denominadas clasificadas en el territorio de la Comunidad Autónoma de Galicia se encuentra regulada

\footnotetext{
${ }^{160}$ De hecho, el contenido del artículo 26, que ordena la comprobación de la autorización ambiental integrada, y del artículo 35, que regula la comprobación de la autorización ambiental unificada, son idénticos.

${ }^{161}$ Según el artículo 42 de la Ley andaluza: "La calificación ambiental tiene por objeto la evaluación de los efectos ambientales de determinadas actuaciones, así como la determinación de la viabilidad ambiental de las mismas y de las condiciones en que deben realizarse".

${ }^{162}$ Un estudio más exhaustivo sobre la Ley andaluza de Gestión Integrada de la Calidad Ambiental y sobre el impacto que sobre ella ha tenido la Directiva de Servicios lo encontramos en ARANA GARCÍA, E. y GRANADOS RODRÍGUEZ, J., "La desaparición de las licencias en las actividades clasificadas incluidas en el ámbito de la Directiva de servicios: el supuesto particular de la legislación ambiental andaluza", en Revista General de Derecho Administrativo, núm. 25, 2010.
} 
en la Ley 1/1995, de 2 de enero, de Protección del Medio Ambiente de Galicia, y en el Decreto 133/2008, de 12 de junio, por el que se regula la evaluación de incidencia ambiental. Para empezar, la Ley clasifica las actividades, según el sistema de protección aplicable a ellas, en actividades de evaluación de impacto ambiental y actividades de evaluación de incidencia ambiental y, por lo tanto, a partir de esta clasificación se determina el procedimiento a seguir para obtener, según el caso, la correspondiente declaración de impacto ambiental o el dictamen de incidencia ambiental de competencia autonómica. De manera que un proyecto, obra o actividad potencialmente lesivo para el medio ambiente, remitido a la Consejería competente en materia de medio ambiente, solo puede estar sometido al procedimiento de evaluación de impacto o al procedimiento de evaluación de incidencia ambiental. Además, el dictamen de incidencia ambiental es requisito previo para la obtención de la licencia de apertura o actividad municipal.

Para conocer qué actividades se someten al procedimiento de evaluación de incidencia ambiental, nos hemos de remitir a los anexos del Decreto 133/2008. El anexo I establece el nomenclátor de actividades sujetas al procedimiento de evaluación de incidencia ambiental, dejando fuera aquellas actividades que necesariamente han de estar sometidas a evaluación de impacto ambiental. En el anexo III se determinan las actividades que quedan excluidas de la evaluación de incidencia ambiental por no superar determinados umbrales allí establecidos. Finalmente, en el anexo II se concretan los criterios objetivos que se han de tener en cuenta para determinar, de manera motivada por la Consejería competente en materia de medio ambiente, el sometimiento o no al procedimiento de evaluación de incidencia ambiental de aquellas actividades molestas, insalubres, nocivas y peligrosas conforme a las definiciones contenidas en la Ley 1/1995 no incluidas ni en el anexo I ni en el anexo III.

Como hemos comentado con anterioridad, la evaluación de incidencia ambiental finaliza con la emisión de un dictamen de incidencia ambiental como trámite previo al otorgamiento de la licencia de actividad. En el supuesto de actividades clasificadas que se hayan de someter a evaluación de impacto ambiental, después de un estudio caso por caso $^{163}$, el procedimiento se tramitará de acuerdo con la normativa reguladora de dicho

\footnotetext{
${ }^{163}$ Nos referimos a aquellas actividades que se han de someter a una evaluación de impacto ambiental en función de las circunstancias y características concretas del proyecto o actividad valoradas caso por caso por el órgano ambiental correspondiente.
} 
procedimiento y la declaración de impacto sustituirá, a todos los efectos, al dictamen de incidencia ambiental ${ }^{164}$.

El procedimiento para la evaluación de incidencia ambiental se inicia con la presentación de la solicitud de licencia de actividad en el ayuntamiento en cuyo término municipal se quiera ubicar la instalación en la que se va a desarrollar la actividad, continúa con diferentes trámites en sede municipal ${ }^{165}$ y se remite el expediente a la Consejería competente en materia de medio ambiente para que solicite informe a los órganos de la Administración autonómica que por la naturaleza de la actividad se deban pronunciar y para que emita el dictamen de incidencia ambiental. El plazo máximo para emitir este dictamen es de tres meses "contados desde la entrada del expediente en la consejería competente en materia de medio ambiente hasta su traslado al Ayuntamiento"166. Una vez que el expediente está de nuevo en el ámbito municipal, el ayuntamiento ha de aplicar una regla coordinadora a la hora de resolver sobre el otorgamiento de la licencia de actividad. Se trata de la siguiente norma: cuando el dictamen de evaluación de incidencia ambiental sea negativo o imponga medidas correctoras que no estén en el proyecto ni en la memoria adjuntada en la solicitud de licencia, tendrá efectos vinculantes para la autoridad municipal que ha de resolver sobre el otorgamiento o denegación de la licencia de actividad ${ }^{167}$. Evidentemente, la licencia de actividades sometida a evaluación de incidencia ambiental incorporará el contenido del dictamen de incidencia ambiental, así como otras prescripciones y medidas necesarias y demás cuestiones de competencia municipal ${ }^{168}$.

Para acabar, pasamos a destacar una serie de cuestiones que se deducen de la normativa objeto de análisis. Por una parte, y al igual que han hecho el resto de comunidades autónomas, el Decreto amplía el régimen de autorización/licencia a muchas actividades no incluidas en la normativa básica estatal. Por otra, al no establecerse de manera

\footnotetext{
${ }^{164}$ Vid. disposición adicional primera del Decreto 133/2008, de 12 de junio, que regula la evaluación de incidencia ambiental.

${ }^{165}$ Emisión del informe sobre compatibilidad de la actividad con los instrumentos de planificación urbanística y las ordenanzas municipales, trámite de información pública, informe razonado del ayuntamiento sobre la incidencia ambiental de la actividad en el ámbito local.

${ }^{166}$ Vid. artículo 11.4 del Decreto 133/2008, de 12 de junio, que regula la evaluación de incidencia ambiental.

${ }^{167}$ Vid. artículo 19 de la Ley 1/1995, de 2 de enero, de Protección del Medio Ambiente de Galicia, y artículo 12.2 del Decreto 133/2008, de 12 de junio, que regula la evaluación de incidencia ambiental.

168 Vid. artículo 13.1 del Decreto 133/2008, de 12 de junio, que regula la evaluación de incidencia ambiental.
} 
específica en el procedimiento de la licencia de actividad el plazo de resolución y notificación ni el régimen del silencio administrativo, hemos de aplicar las disposiciones de la Ley 30/92, de 26 de noviembre, de Régimen Jurídico de las Administraciones Públicas y del Procedimiento Administrativo Común, que determinan que el plazo máximo de resolución y notificación será de tres meses a contar desde la fecha en que la solicitud haya tenido entrada en el registro del órgano competente para su tramitación, con la posibilidad de suspender el transcurso del plazo cuando, como el caso que nos ocupa con el dictamen de incidencia ambiental, deban solicitarse informes que sean preceptivos y determinantes del contenido de la resolución por el tiempo que medie entre la petición y la recepción del informe, sin que este plazo de suspensión pueda superar los tres meses. Además, a falta de pronunciamiento en contrario por parte de la Ley gallega objeto de estudio, el transcurso del plazo máximo sin haberse notificado resolución expresa legitima al interesado para entender la solicitud estimada por silencio administrativo, siempre, entendemos, que la Administración autonómica no haya emitido un dictamen de incidencia ambiental negativo. Resaltamos también que la normativa gallega no determina un plazo de validez de la autorización. Por lo tanto, ni en el ámbito del silencio ni en el ámbito de la validez de las autorizaciones se excepciona la regla general establecida en la normativa relativa al libre acceso a las actividades de servicios.

\section{Asturias}

La comunidad autónoma que ha regulado sobre la materia de manera más incidental y residual y que, además, lo ha hecho en tiempos más pretéritos ha sido la asturiana. Esta somera regulación se debe a que en el Principado de Asturias aún está en vigor el Decreto 2414/1961, de 30 de noviembre, por el que se aprueba el Reglamento de Actividades Molestas, Insalubres, Nocivas y Peligrosas ${ }^{169}$. En este contexto nos encontramos con dos textos normativos brevísimos. En concreto, la Ley 12/1984, de 21 de noviembre, sobre delegación de atribuciones en materia de informe previo de actividades clasificadas de la Agencia de Medio Ambiente del Principado de Asturias a

\footnotetext{
${ }^{169}$ Como hemos señalado con anterioridad, este decreto ha sido derogado por la Ley 34/2007, de 15 de noviembre, de Calidad del Aire y Protección de la Atmósfera, aunque en la disposición derogatoria única se establece lo siguiente: "No obstante, el citado Reglamento mantendrá su vigencia en aquellas comunidades y ciudades autónomas que no tengan normativa aprobada en la materia, en tanto no se dicte dicha normativa”. Situación esta última ante la que nos encontramos.
} 
los concejos (ayuntamientos), establece, entre otras cuestiones, una remisión al Reglamento para determinar las actividades cuyo informe puede ser objeto de delegación y los medios personales y materiales de los que deben disponer las oficinas o servicios técnicos de los concejos (ayuntamientos) para poder delegar la facultad de informe. Esta remisión se concreta a través del Decreto 139/1984, de 12 de diciembre, sobre delegación de atribuciones en materia de actividades molestas, insalubres, nocivas y peligrosas en los concejos (ayuntamientos) a través de la Agencia de Medio Ambiente.

A partir de esta realidad llegamos a las siguientes conclusiones en relación con el régimen aplicable a las actividades clasificadas en el Principado de Asturias:

— Las actividades del anexo I de la Ley 16/2002, de 1 de julio, de Prevención y Control Integrados de la Contaminación, siguen el régimen de autorización autonómica, con la intervención del ayuntamiento en cuyo territorio se ubique la instalación, regulado por esta norma básica.

- El resto de actividades clasificadas se someten a licencia municipal, estableciendo una diferenciación en la tramitación del procedimiento en función de si las actividades se encuentran o no recogidas en el anexo del Decreto 139/1984, de 12 de diciembre, sobre delegación de atribuciones en materia de actividades molestas, insalubres, nocivas y peligrosas en los concejos (ayuntamientos) a través de la Agencia de Medio Ambiente. Si la actividad no está incluida en el anexo del citado Decreto, en el procedimiento interviene la Agencia de Medio Ambiente del Principado emitiendo un informe cuyo contenido se incluirá en el condicionado de la licencia. En cambio, si la actividad está incluida en el anexo del Decreto y se ha materializado la delegación de la competencia de informe, el procedimiento se desarrolla totalmente en sede municipal. Ahora bien, en ambos supuestos el Reglamento de Actividades Molestas, Insalubres, Nocivas y Peligrosas establece un régimen de licencia individual para cada establecimiento donde el sentido del silencio de la Administración es positivo, salvo que el informe emitido por el órgano competente haya sido desfavorable, y donde, si no se dan circunstancias sobrevenidas, se determina una validez indefinida de la licencia.

En conclusión, en esta comunidad la regulación continúa estableciendo un régimen de intervención preventivo clásico para todas las actividades clasificadas sin excepción. 


\section{Castilla-La Mancha}

En la Comunidad Autónoma de Castilla-La Mancha también continúa en vigor el Decreto 2414/1961, de 30 de noviembre, por el que se aprueba el Reglamento de Actividades Molestas, Insalubres, Nocivas y Peligrosas ${ }^{170}$, y es por este motivo que en esta comunidad tenemos dos textos normativos que se dedican básicamente a adaptar el reglamento de actividades clasificadas a la nueva realidad posconstitucional. En concreto, el Decreto 79/1986, de 11 de julio, sobre servicios y funciones en materia de actividades molestas, insalubres, nocivas y peligrosas, crea diversos órganos autonómicos para articular las competencias en este ámbito y determina su composición, sus funciones y régimen jurídico. Con posterioridad, el Decreto 37/1998, de 12 de mayo, sobre régimen de delegación de competencias en los ayuntamientos y mancomunidades, regula las condiciones, el procedimiento y las actividades susceptibles de delegación de las funciones atribuidas a las comisiones provinciales de saneamiento, que son órganos autonómicos, en los municipios y las mancomunidades de Castilla-La Mancha.

Todo esto significa que, al igual que sucede en el Principado de Asturias, el régimen a aplicar a las actividades clasificadas en la Comunidad Autónoma de Castilla-La Mancha será el siguiente:

— Las actividades del anexo I de la Ley 16/2002, de 1 de julio, de Prevención y Control Integrados de la Contaminación, siguen el régimen de autorización autonómica, con intervención del ayuntamiento en cuyo territorio se ubique la instalación, regulado por esta norma básica.

- El resto de actividades clasificadas se someten a un régimen de licencia municipal individual para cada establecimiento donde el sentido del silencio de la Administración es positivo, salvo que el informe emitido por el órgano competente haya sido desfavorable, y donde, si no se dan circunstancias sobrevenidas, se determina una validez indefinida de la licencia.

\section{Extremadura}

\footnotetext{
${ }^{170}$ Vid. nota a pie de página ut supra.
} 
En materia de actividades clasificadas la Comunidad Autónoma de Extremadura dispone de una normativa, como veremos, aprobada con posterioridad a la normativa estatal de transposición de la Directiva de Servicios, y, por lo tanto, se trata de una regulación que tiene en cuenta en parte los nuevos postulados en la materia. Nos referimos a la Ley 5/2010, de 23 de junio, de Prevención y Calidad Ambiental de la Comunidad Autónoma de Extremadura, que pretende ser una norma única y omnicomprensiva en su ámbito territorial en relación con la prevención y la calidad ambiental, y al Decreto 81/2011, de 20 de mayo, por el que se aprueba el Reglamento de Autorizaciones y Comunicación Ambiental de la Comunidad Autónoma de Extremadura.

El cuerpo normativo acabado de citar somete a las actividades susceptibles de afectar a la salud de las personas o al medio ambiente a diferente régimen jurídico en función de la ubicación de la actividad en uno u otro anexo. Esta distribución en los anexos se ha realizado, evidentemente, teniendo en cuenta el potencial lesivo de la actividad sobre la salud y el medio ambiente. De acuerdo con lo que acabamos de afirmar, hemos de distinguir entre: la autorización ambiental integrada, que se aplica a las actividades del anexo V; la autorización ambiental unificada para las actividades del anexo VI; y la comunicación ambiental reservada para las actividades incluidas en el anexo VII.

La autorización ambiental integrada extremeña sigue la regulación de la autorización ambiental integrada establecida en la Ley 16/2002, de 1 de julio, de Prevención y Control Integrados de la Contaminación, y, por lo tanto, se someten a autorización ambiental integrada la construcción, el montaje, la explotación, el traslado y la modificación sustancial de las actividades incluidas en el anexo $\mathrm{V}$ de la Ley autonómica. Actividades que coinciden con las del anexo I de la Ley básica estatal.

La autorización ambiental unificada es también un instrumento de intervención autonómico que tiene por objeto integrar en un solo acto de intervención las autorizaciones, los informes sectoriales preceptivos y las prescripciones necesarias en materia de medio ambiente en relación con una actividad determinada ubicada en el anexo VI. De acuerdo con lo que acabamos de decir, también se integran en este procedimiento las actuaciones relativas a la evaluación de impacto ambiental y la intervención de los ayuntamientos en todos aquellos aspectos que son de su competencia. El plazo de resolución que pone fin al procedimiento no puede ser superior a seis meses. Si este se supera sin haberse notificado la resolución, se 
considerará la autorización como desestimada. Como regla general, se otorga la autorización con carácter indefinido, sin perjuicio de la necesidad de renovar las autorizaciones sectoriales que sean pertinentes para el ejercicio de la actividad en los períodos establecidos por la normativa vigente ${ }^{171}$.

Ambas autorizaciones preceden a otras autorizaciones o licencias municipales que son competencia de los ayuntamientos como, por ejemplo, las licencias urbanísticas (licencia de obras, edificación e instalación) ${ }^{172}$ y las licencias de usos y actividades ${ }^{173}$.

Una vez otorgadas las autorizaciones estudiadas, las instalaciones no podrán iniciar la actividad sin que previamente se compruebe el cumplimiento de las condiciones fijadas en aquellas y se otorgue la licencia municipal de usos y actividades establecida en la Ley 15/2001, de 14 de diciembre, del Suelo y Ordenación Territorial de Extremadura. Para ello, el titular de la autorización ha de presentar ante el órgano ambiental la solicitud de inicio de actividad. A través de la visita de comprobación, los servicios técnicos del órgano ambiental de la Comunidad Autónoma han de comprobar que las instalaciones se ajustan al proyecto aprobado y al condicionado de la autorización y que se cumplen las condiciones fijadas en la autorización ambiental integrada o en la autorización ambiental unificada. Todo ello lo han de reflejar los servicios técnicos en un informe que se remitirá al ayuntamiento correspondiente para que pueda resolver, cuando proceda, sobre la licencia municipal de usos y actividades. La comprobación y el informe se han de realizar en el plazo de un mes desde que lo solicita el titular. Si transcurre el plazo sin que se otorgue la conformidad de manera expresa, se entenderá que la conformidad ha sido otorgada tácitamente ${ }^{174}$. No podemos dejar acabar este parágrafo sin antes comentar que el control de inicio de actividad se podría haber

\footnotetext{
${ }^{171}$ Vid. artículos 54 a 58 de la Ley 5/2010, de 23 de junio, de Prevención y Calidad Ambiental de la Comunidad Autónoma de Extremadura.

${ }^{172}$ La disposición adicional segunda del Decreto 81/2011, de 20 de mayo, por el que se aprueba el Reglamento de Autorizaciones y Comunicación Ambiental de la Comunidad Autónoma de Extremadura, establece que "la resolución del órgano ambiental por la que se otorga la autorización ambiental será previa al otorgamiento de la licencia de obras, edificación e instalación por parte del Ayuntamiento correspondiente, para el cual, la autorización ambiental será vinculante cuando implique la denegación de licencia o la imposición de medidas correctoras".

${ }^{173}$ Vid. artículos 48.3, 54.3 y 64.5 de la Ley 5/2010, de 23 de junio, de Prevención y Calidad Ambiental de la Comunidad Autónoma de Extremadura.

174 Vid. artículo 64 de la Ley 5/2010, de 23 de junio, de Prevención y Calidad Ambiental de la Comunidad Autónoma de Extremadura, y artículo 34 del Decreto 81/2011, de 20 de mayo, por el que se aprueba el Reglamento de Autorizaciones y Comunicación Ambiental de la Comunidad Autónoma de Extremadura.
} 
articulado perfectamente a través de un instrumento menos oneroso como la comunicación previa.

La comunicación ambiental tiene por objeto prevenir y controlar, en el marco de las competencias municipales, los efectos sobre la salud humana y el medio ambiente de las actividades de escasa incidencia ambiental que se recogen en el anexo VII de la Ley. Se trata de un número considerable de actividades que, además, resultan ser las más comunes y, por lo tanto, las más numerosas. Además, los ayuntamientos podrán aumentar en sus ordenanzas municipales el listado de actividades que se han de someter a comunicación ambiental, siempre que no se incluyan actividades sometidas a autorización. La comunicación ambiental deberá presentarse ante el ayuntamiento en cuyo término municipal pretenda desarrollarse la actividad y contendrá en todo caso la siguiente documentación:

— Proyecto o memoria en donde se describan la actividad y sus principales impactos ambientales.

- Certificación que acredite que la actividad y las instalaciones se adecuan al proyecto o a la memoria y que cumplen todos los requerimientos y las condiciones técnicas determinados por la normativa ambiental.

De acuerdo con lo que establece la normativa, el orden de la intervención administrativa de estas actividades sometidas a comunicación previa es el que sigue. En primer lugar, se ha de obtener la correspondiente licencia o comunicación urbanística $y$, una vez acabadas las obras e instalaciones, hay que presentar la comunicación ambiental y, con posterioridad, el Ayuntamiento podrá otorgar la licencia de usos y actividades ${ }^{175}$.

\section{CONCLUSIONES}

Después de realizar una explicación sobre las determinaciones de cada una de las legislaciones de las comunidades autónomas y un breve análisis sobre la adecuación de estas normativas a los postulados de la Directiva de Servicios y la normativa estatal que la transpone, en este apartado de conclusiones nos limitaremos a realizar valoraciones de conjunto, intentando destacar las líneas generales que vislumbramos.

175 Vid. artículos 68 a 74 Ley 5/2010, de 23 de junio, de Prevención y Calidad Ambiental de la Comunidad Autónoma de Extremadura. 
Partiendo de la base de que, más allá de la legislación básica, las diferentes comunidades autónomas tienen un amplio margen para interpretar la necesidad de utilizar instrumentos restrictivos que constriñen la libertad de establecimiento de las actividades de servicios en aras de la defensa de la protección del medio ambiente y del entorno urbano, siempre que estos mecanismos sean proporcionados para el objetivo propuesto y no discriminatorios, nos encontramos, como hemos visto, con multitud de realidades. En este sentido, hay comunidades que aún se rigen por el Reglamento de actividades clasificadas del año 1961, comunidades que, aunque tienen una regulación que articula la intervención administrativa en función del potencial de impacto de la actividad, no han ido más allá en la senda liberadora y comunidades que han reformado su normativa sobre la materia para acercarse a los nuevos postulados que dicta la normativa sobre libre acceso a las actividades de servicios.

En este intento de algunas comunidades autónomas de acercar su normativa a los nuevos criterios reguladores de los servicios en el mercado interior no vemos, en algunas ocasiones, una actitud muy decidida y clara. Parece que, por una parte, se quieran adoptar nuevos instrumentos menos onerosos que favorezcan esta libertad de establecimiento, pero que, por otra, el legislador no se acabe de mostrar confiado en que estos instrumentos sirvan para proteger el medio ambiente y el entorno urbano de manera adecuada. De manera que finalmente y en algunos casos esta corriente reformadora se ha quedado a medio camino ${ }^{176}$ o sin rematar ${ }^{177}$.

Del análisis de este margen de libertad que tienen las comunidades autónomas para interpretar la necesidad de utilizar instrumentos administrativos limitativos con el objetivo de proteger el medio ambiente y el entorno urbano concluimos que, por ahora, muchas comunidades autónomas —como Madrid, Asturias, Castilla-La Mancha, Cantabria, Navarra, La Rioja, Andalucía y Murcia - han optado por no reformar su normativa $\mathrm{y}$, por lo tanto, considerar que los instrumentos de intervención administrativa establecidos en su legislación son los necesarios para proteger el medio ambiente y el entorno urbano. Al respecto, hemos de manifestar que muchas de las medidas que mantienen estas comunidades autónomas en su normativa no son proporcionadas desde el momento en que, como hemos comentado en su estudio

\footnotetext{
${ }^{176}$ Es el caso, como vamos a ver, de Aragón, Castilla y León, Valencia y Extremadura.

${ }^{177}$ Es el caso de la normativa de Canarias, que requiere de la aprobación de un decreto para que la reforma sea operativa.
} 
individualizado, se podría proteger igualmente el medio ambiente y el entorno urbano con medidas menos onerosas. Otras comunidades autónomas, como hemos mencionado con anterioridad, han modificado su normativa, pero con prevenciones también difíciles de justificar, y, finalmente, son pocas las comunidades autónomas — precisamente las más industrializadas como Cataluña y el País Vasco, que en su momento también fueron pioneras en transponer la Directiva sobre prevención y control integrados de la contaminación a su normativa, o Baleares, que destaca por el gran desarrollo del sector servicios en su territorio- que han modificado su normativa plenamente, de manera que no han permitido la persistencia de ningún instrumento no justificado para proteger el medio ambiente y el entorno urbano. En el caso de Cataluña consideramos que la normativa se ha excedido en el sentido liberalizador, dejando demasiadas actividades en manos de la comunicación previa, algunas de las cuales se puede considerar que no son siempre de escasa incidencia ambiental, y abriendo la posibilidad de que, a través de ordenanzas municipales, actividades sometidas a licencia ambiental pasen al régimen de comunicación previa si se dan determinados requisitos. Además, todas estas actividades sometidas a comunicación previa no tienen previsto un control ex post regulado, de manera que este se hace depender exclusivamente de la actividad inspectora que se realice.

Las comunidades autónomas que utilizan las figuras de la declaración responsable y de la comunicación previa lo hacen de manera muy heterogénea. En algunos supuestos se diseñan unos regímenes de comunicación previa que se alejan de su concepción originaria y se acercan a la autorización y a la licencia. Este fenómeno se plasma cuando vemos que se ordenan regímenes de comunicación previa en los que:

— Se establece un lapso de tiempo para que la Administración se pronuncie.

- Se requiere el paso del tiempo sin manifestación en contrario para poder ejercer la actividad.

- Muchas veces no se puede iniciar la actividad desde el día de la presentación de la comunicación y se exige una visita de comprobación posterior.

En el trabajo, cuando nos hemos encontrado ante estos supuestos, nos hemos referido a comunicaciones previas impropias, comunicaciones más nominales que sustantivas o reales $^{178}$. En nuestra opinión, esta es una manifestación más del fenómeno que hemos

\footnotetext{
${ }^{178}$ Son los casos, por ejemplo, de Castilla y León y Valencia.
} 
apuntado más arriba del "quiero, pero me da miedo, del sí, pero no". Nuestra posición al respecto es que estos medios se pueden utilizar sin reparos para habilitar el establecimiento de instalaciones y actividades que tienen un potencial bajo o escaso de afectar al medio ambiente, a la salud de las personas y a la seguridad, y también para articular la puesta en marcha o apertura de las actividades sometidas a autorización o a licencia, siempre que se exija en ambos casos como requisito la presentación de un certificado, emitido por una entidad colaboradora de la Administración acreditada o por los servicios técnicos municipales, que establezca que la instalación o actividad cumple el proyecto y el estudio ambiental presentados y la legalidad vigente y que se han realizado las comprobaciones pertinentes relativas a las emisiones al medio, y, además, si se utiliza para habilitar la puesta en marcha de las actividades, también tendrá que acreditar que la actividad cumple las condiciones y medidas correctoras impuestas en el permiso administrativo. Por lo tanto, consideramos equivocado partir de la base de que la comunicación previa es un medio poco eficaz para proteger el medio ambiente y el entorno urbano. Su efectividad dependerá fundamentalmente de los requisitos que se exijan por parte de la normativa para poder ejercer un derecho o iniciar una actividad. Se puede configurar perfectamente, como hemos visto, como un instrumento que exige la presentación de certificados que implican la realización de actuaciones de control ex ante por una entidad colaboradora de la Administración o por los servicios técnicos de la Administración municipal.

También queremos señalar que algunas comunidades autónomas, como La Rioja, Cataluña o Extremadura, han establecido el sentido del silencio como negativo en la regulación del régimen de licencia ambiental o en la autorización ambiental unificada. Nosotros consideramos correcta esta disposición siempre que los procedimientos en que se integra este silencio estén destinados a actividades que tienen un potencial de impacto relevante para el medio ambiente, para las personas y para la seguridad. Por lo tanto, en estos casos existirían razones imperiosas de interés general que determinarían la necesidad y la proporcionalidad de la medida. El problema surge cuando el régimen de licencia que establece el silencio en sentido negativo va destinado también a algunas actividades con escasa incidencia ambiental, como sucede en el caso de La Rioja.

Ya hemos anticipado y explicitado en estas conclusiones que algunas comunidades autónomas mantienen en su normativa instrumentos y mecanismos limitativos y onerosos que, según nuestro parecer, no están justificados porque no son necesarios ni 
proporcionados para proteger el medio ambiente y el entorno urbano desde el momento en que se podrían proteger igualmente con instrumentos menos costosos en términos del ejercicio de la libertad de servicios en el mercado interior. Pasamos a ver los mecanismos que aún nos quedan por referenciar:

- Algunas comunidades autónomas, como Andalucía, La Rioja, Cantabria y Navarra, establecen el régimen de licencia para muchas actividades prácticamente inocuas. El problema es que en su normativa meten en el mismo saco y someten al mismo régimen actividades con un potencial de incidencia ambiental muy variado, no estableciendo un anexo diferenciado de actividades inocuas o con un potencial de incidencia ambiental bajo que seguirían un régimen menos oneroso.

— La Comunidad Autónoma de Murcia, en relación con las actividades del anexo II — que se consideran actividades inocuas y exentas de calificación ambiental y, por lo tanto, son actividades con escasísima o nula incidencia ambiental-, establece en su normativa la posibilidad de que los ayuntamientos sustituyan en sus ordenanzas el régimen de licencia por el régimen de comunicación previa. Criticamos que el legislador deje en manos de los ayuntamientos la sustitución de un régimen que, de acuerdo con los postulados de nuestra normativa de servicios, no está justificado por otro régimen como la comunicación previa, que es el correcto para el tipo de actividades que nos encontramos. Tendría que ser el legislador autonómico quien ordenara esta cuestión, de acuerdo con el principio de proporcionalidad y necesidad, para toda la comunidad autónoma.

- Otras comunidades autónomas, como Aragón, Navarra, La Rioja y Extremadura, mantienen de manera injustificada dos tipos de autorizaciones y/o licencias, una para la instalación de la actividad y otra para su apertura. Esta segunda no la consideramos ni necesaria ni proporcionada porque la protección del medio ambiente y del entorno urbano quedaría igualmente garantizada a través de la comunicación previa o de la declaración responsable, donde se estableciera como requisito, entre otros, la acreditación, a través de un certificado, de que la actividad cumple las condiciones y medidas correctoras impuestas en el permiso administrativo correspondiente.

Consideramos que el Real Decreto-Ley 19/2012, de 25 de mayo, de Medidas Urgentes de Liberalización del Comercio y de Determinados Servicios, que hemos citado varias veces a lo largo de este trabajo, ha sido recientemente aprobado por varios motivos, 
entre los que se encuentra, sin duda, la falta de adaptación, que hemos evidenciado en este trabajo, de la normativa de algunas comunidades autónomas a las exigencias de la normativa de libre acceso a las actividades de servicios. Esta realidad, junto con la gravedad de la crisis económica que está viviendo el país, ha empujado al Estado a tomar cartas en el asunto, escudándose, entre otros, en los títulos competenciales 149.1.1, 149.1.13 y 149.1.18 de la Constitución, liberando al comercio minorista y a determinados servicios, concretados en el anexo de la norma, de la exigencia de licencia ambiental.

\section{BIBLIOGRAFÍA}

AGUAdO CUDOLÀ, V. y NOGUERA DE LA MUELA, B. (dirs.), El impacto de la Directiva de Servicios en las Administraciones Públicas: aspectos generales y sectoriales, Atelier, Barcelona, 2012.

ARANA GARCÍA, E. y GRANADOS RODRÍGUEZ, J., "La desaparición de las licencias en las actividades clasificadas incluidas en el ámbito de la Directiva de servicios: el supuesto particular de la legislación ambiental andaluza", en Revista General de Derecho Administrativo, núm. 25, 2010.

CASADO CASADO, L., "Novedades en el régimen de prevención y control ambiental de actividades en Cataluña: Retroceso en la protección del medio ambiente versus promoción de la actividad económica", en Revista Catalana de Dret Ambiental, vol. III, núm. 1, 2012.

ESTEVE GARCÍA, F., "Los diferentes instrumentos de liberalización incluidos en la Directiva 2006/123 de servicios”, en Revista catalana de dret públic, núm. 42, 2011.

FORTES MARTÍN, A., "La libertad de establecimiento de los prestadores de servicios en el mercado interior bajo el nuevo régimen de la Directiva 2006/123 de 12 de diciembre", en De la Cuadra-Salcedo Fernández del Castillo, T. (dir.), El mercado interior de servicios en la Unión Europea. Estudios sobre la Directiva 123/2006/CE relativa a los servicios en el mercado interior, Marcial Pons, Madrid, 2009.

FUENTES LÓPEZ, M., "Luces y sombras en la incorporación de la directiva de servicios”, en Revista catalana de dret públic, núm. 42, 2011. 
HINOJOSA MARTÍNEZ, L., El reparto de competencias entre la Unión Europea y sus Estados miembros, Tirant lo Blanch, Valencia, 2006.

LINDE PANIAGUA, E., "Notas sobre el objeto, ámbito y reglas de aplicación de la directiva relativa a los servicios en el mercado interior", en Revista de Derecho de la Unión Europea, núm. 14, 2008.

— "Libertad de establecimiento de los prestadores de servicios en la directiva relativa a los servicios en el mercado interior", en Revista de Derecho de la Unión Europea, núm. $14,2008$.

LOZANO CUTANDA, B., "Ley Ómnibus: silencio administrativo, declaración responsable y comunicación previa”, en Diario La Ley, núm. 7339, 2010.

MONTERO PASCUAL, J., "La libre prestación de servicios en la directiva relativa a los servicios en el mercado interior", en Revista de Derecho de la Unión Europea, núm. $14,2008$.

MUÑOZ MACHADO, S., "Ilusiones y conflictos derivados de la directiva de servicios”, en Revista General de Derecho Administrativo, núm. 21, 2009.

NOGUEIRA LÓPEZ, A., "Entidades colaboradoras de la Administración, libre prestación de servicios y régimen de control preventivo de actividades", en Revista Aranzadi de Derecho Ambiental, núm. 16, 2009.

— "La termita Bolkestein", en El cronista del Estado social y democrático de derecho, núm. 22, 2011.

PERNAS GARCÍA, J., "El efecto desregulador de la Directiva de servicios y su incidencia en la ordenación administrativa ambiental", en Nogueira López, A. (dir.), La termita Bolkestein. Mercado único vs. Derechos ciudadanos, Thomson Reuters, Cizur Menor, 2012.

PLAZA MARTÍN, C., Derecho ambiental de la Unión Europea, Tirant lo Blanch, Valencia, 2005.

RAZQUIN LIZARRAGA, J., "El impacto de la Directiva de servicios en el procedimiento administrativo: autorización, declaración responsable y comunicación", en Revista Jurídica de Navarra, núm. 49, 2010. 
RIVERO ORTEGA, R., "Simplificación administrativa y Administración electrónica: objetivos pendientes en la transposición de la directiva de servicios", en Revista catalana de dret públic, núm. 42, 2011.

RODRÍGUEZ FONT, M., "Técnicas de control en la transposición de la Directiva de servicios: Comunicación previa y declaración responsable”, en Nogueira López, A. (dir.), La termita Bolkestein. Mercado único vs. Derechos ciudadanos, Thomson Reuters, Cizur Menor, 2012.

SANZ RUBIALES, I., "Medio ambiente y Directiva de servicios en Castilla y León”, en Vicente Blanco, D. y Rivero Ortega, R. (dirs.), Impacto de la transposición de la Directiva de servicios en Castilla y León, Consejo Económico y Social de Castilla y León, Valladolid, 2010. Edición electrónica recuperada el 4 de junio de 2012 de $<$ http://www.cescyl.es/pdf/coleccionestudios/ce13servi.pdf $>$.

URRUTIA LIBARONA, I., Marco jurídico del libre acceso a las actividades de servicios y su ejercicio en la Comunidad Autónoma del País Vasco, Instituto Vasco de Administración Pública, Oñate, 2010. 